A C G publications journal of chemical metrology

\title{
Study the effect of different dyeing conditions of extracted natural dye from leaves of neem on silk fabrics
}

\author{
Nabawia A. Abdel-Zaher ${ }^{1}$, Manal T.H. Moselhey ${ }^{2}{ }^{2}$ and \\ Osiris W. Guirguis $\odot^{3 \text {, * }}$ \\ ${ }^{1}$ Textile Metrology Lab, National Institute for Standards, Giza, Egypt \\ ${ }^{2}$ Al-Safwa High Institute of Engineering, Cairo, Egypt \\ ${ }^{3}$ Biophysics Department, Faculty of Science, Cairo University, Giza, Egypt
}

(Received January 29, 2017; Revised March 10, 2018; Accepted March 15, 2018)

\begin{abstract}
The aim of the present work was to evaluate the effect of artificial day light for $160 \mathrm{~h}$ on silk fabrics dyeing with different conditions such as; different dye bath $\mathrm{pH}$ values, different dyeing temperatures, and different dyeing times; of extracted natural dye from Azadirachta indica (neem) leaves. The reflectance spectra of the untreated and treated silk fabrics were followed using spectrophotometer technique. The effects of dyeing conditions in the optical parameters, such as; CIE tristimulus values, color parameters, absorption coefficient as well as extinction coefficient and color strength, were determined before and after exposure. The obtained results indicate that the silk fabrics were found to be highly dependent on either of these different dyeing conditions and/or artificial day light exposure. Also, variations in the values of the optical band gap energy were detected. Improvement in the dyeing process were produced which may be attributed to the induced structural change due to the variation in the chemical bonds in silk fabrics. The present work gives the chance to produce a new traditional natural dye to meet the environmental future demands technology of high quality fantastic dyed pattern.
\end{abstract}

Keywords: Natural dye; neem plant; silk fabrics; dyeing conditions; optical properties. C 2018 ACG Publications. All rights reserved.

\section{Introduction}

Silk is a fine lustrous fiber which represents one of a natural material consists of polypeptide protein which is composed of 18 amino acids with various reactive functional groups including hydroxyl and amine groups such as: Threonine, Serine, Lysine, Arginine, Histidine and Tryptophan [1]. The fibrous proteins are spun into yarn by a variety of insects and spiders [2]. Silk fiber composed mainly of two types of biomacromolecules constructed in two based protein layers; fibroin (about $75 \%$ by weight) and sericin (about $25 \%$ by weight) [3]. The sericin strengthens the silk fiber and makes it lack luster. Fibroin consists of high proportions of amino acids such as alanine, glycine, and serine. Fibroin is a filamentous protein in an inner layer coated with a glue-like sericin (a non-filamentous protein) in an outer layer which acts like an envelope to bind the fibroins together and also other impurities such as pigments, wax, carbohydrates, and inorganic salts [4]. Silk fiber has many advantages such as: it is a long-term biodegradable [5,6]; good biocompatible [7]; it has superior mechanical properties [5]; it has low inflammatory reaction in a body [8]; it is highly crystalline

\footnotetext{
${ }^{*}$ Corresponding author: E-mail: osiris wgr@yahoo.com
} 
with a well-aligned structure and it is easy to modify; as well as it has high strength, extensibility, and compressibility [9-12]. Silk fiber was used as a premium material for textile manufacturing, cosmetics, and in biotechnological fields [13-16]. In addition, according to the above mentioned properties, silk was represented as a good biomaterial and has attracted the attention of biomedical researchers to be applied in different biomedical fields [17]. These applications include: the creation of artificial ear drums [18]; a bone substitute and membranes for guided bone regeneration [19,20]; tissue engineering scaffolds $[21,22]$ and stitches in clinic surgery [5]; burn dressings [23; nerve guidance conduit [24]; and for gene delivery [25].

As silk is a kind of natural protein fiber; it was bonded to dyes mainly by ionic interaction between its carboxyl groups and the free chemical groups of dyes. As mentioned silk fiber is a protein-based and its chemical formula is $\mathrm{NH}_{2}$.CHR.COOH. The most important ones for dyeing of silk are $\mathrm{COOH}$ and $\mathrm{NH}_{2}$ [26]. In dying process, dyes in solutions are adsorbed and diffused into the fiber, establishing with it physicochemical interactions [27].

At present, more than 200 plants with insecticidal activities are known. Among the natural products, Azadirachtin was one of the most promising natural compounds. It is an active compound extracted from the Azadirachta indica A. Juss (neem) tree belongs to the botanical family Meliaceae. Azadirachta indica (neem) commonly called 'India Lilac' or 'Margosa'. Neem tree has adaptability to a wide range of climatic, topographic and edaphic factors. It needs little water and plenty of sunlight [28]. Neem has many properties such as [29]; antiviral, antifungal, antibacterial and insecticidal, biodegradable, least persistence and least toxic to non-target organisms as well as economic and easy availability. Chemical investigation on the products of the neem tree indicated that more than 135 compounds have been isolated from different parts of neem [30]. Due to these properties; the popularity of the neem plant products is increasing.

Earlier studies by several workers [31,32] on the plant Azadirachta indica (neem) have reported that it contains active substances with multiple medicinal properties. For example, in traditional medicine, neem is used as a source of many therapeutic agents and its twigs provide a chewing stick.

In the present work, neem as a natural dye is used for dyeing a natural fabric (silk). The effect of artificial day light for $160 \mathrm{~h}$ on silk fabric dyeing with different conditions such as; different $\mathrm{pH}$ values, different dyeing temperatures, and different dyeing times, of extracted natural dye from Azadirachta indica leaves of neem was evaluated by using a spectrophotometer tool. The following optical parameters including: CIE tristimulus values $\left(\mathrm{x}_{\mathrm{r}}, \mathrm{y}_{\mathrm{r}}\right.$ and $\left.\mathrm{z}_{\mathrm{r}}\right)$, color parameters $\left(\mathrm{L}^{*}, \mathrm{a}^{*}, \mathrm{~b}^{*}, \mathrm{~W}, \mathrm{C}^{*}, \mathrm{H}^{*}\right.$ and $\left.\Delta \mathrm{E}^{*}\right)$, absorption coefficient $(\alpha)$, extinction coefficient $(\mathrm{K})$ and color strength $(\alpha / \mathrm{S})$, were detected from the reflectance spectra.

\section{Experimental}

\subsection{Silk Fabric Samples}

Pure white silk fabrics $\left(100 \%, 55 \mathrm{~g} / \mathrm{m}^{2}\right.$ in weight and $0.06 \mathrm{~cm}$ in thickness) were produced in Akhmim, Egypt. The supplied fabrics were used without any purification. The fabrics were soaked in a solution of 0.5 $\mathrm{g} / \mathrm{L}$ sodium carbonate and $2 \mathrm{~g} / \mathrm{L}$ non-ionic detergent using liquor ratio $1: 50$ at temperature $60{ }^{\circ} \mathrm{C}$ for 15 minutes and then, were washed with tap water and dried at ambient conditions.

\subsection{Extraction and Identification of the Neem Dye}

Dried leaves of neem plant were used for obtaining the neem dye without using any mordant in the dyeing process. After crushing $50 \mathrm{~g}$ of the dried leaves were immersed in $0.5 \mathrm{~L}$ of distilled water and boiled for 60 minutes for $1 \mathrm{~h}$ and then filtrate to drain off undesired portion. After filtration the absorption spectrum of the aqueous extracted neem leaves in the UV-visible range $(250-700 \mathrm{~nm})$ was evaluated by using a Shimadzu (VIS) Double Beam Spectrophotometer with standard illuminant C (1174.83) model V-530 and band width $2.0 \mathrm{~nm}$ with accuracy $\pm 0.05 \%$ to evaluate the optical density of the extracted solution and was shown in Figure 1. As noticed from the figure, three peaks were detected: (1) at about $320 \mathrm{~nm}$ of optical density 3.765 ; (2) at about $370 \mathrm{~nm}$ of optical density 3.402; and (3) at about $400 \mathrm{~nm}$ of optical density 3.569 . 


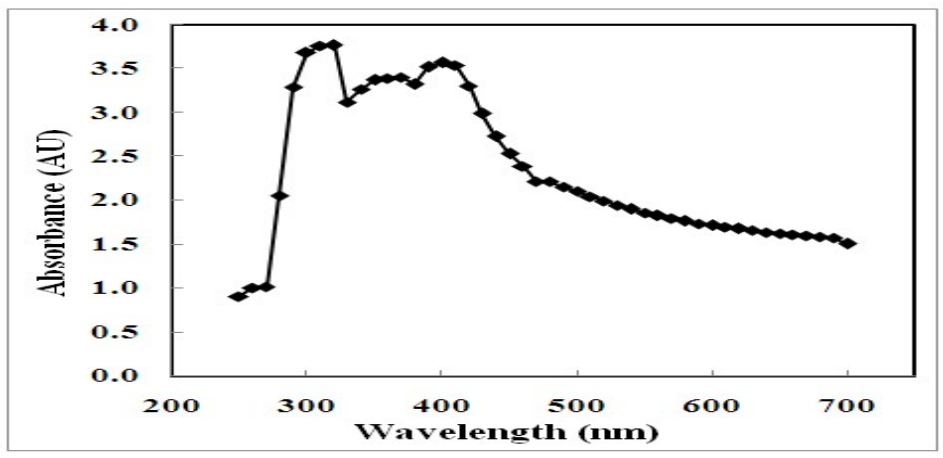

Figure 1. The absorption spectrum of the aqueous extract of the neem leaves.

\subsection{Dyeing Method}

Silk fabrics were dyed by neem dye using a liquor ratio of 1:50 [33]. The fabrics were divided into three groups. The samples of the first group were dyed at a temperature of $60{ }^{\circ} \mathrm{C}$ for 60 minutes in dye baths of different $\mathrm{pH}$ values $(3,4,5,6,7,8$ and 9$)$. The samples of the second group were dyed in a medium of $\mathrm{pH}=$ 6 for 60 minutes and different temperatures $20,40,60$, and $80^{\circ} \mathrm{C}$. The samples of the third group were dyed at temperature of $60^{\circ} \mathrm{C}$ and a medium of $\mathrm{pH}=6$ in a dye bath for different times $15,30,45$ and 60 minutes.

\subsection{Spectroscopic Measurements}

A Shimadzu Vis-Double Beam Spectrophotometer with standard illuminant C (1174.83) model V-530 was carried out to study the reflectance spectra of the undyed and dyed silk fabrics under different conditions $(\mathrm{pH}$ values, temperatures and times) as well as unexposed and exposed groups in the visible region (400-700 $\mathrm{nm})$.

All the untreated and treated silk fabrics were exposed to artificial day light using Tera Light Fastness Tester [Patent No. 15182., Egypt, 1981] for $160 \mathrm{~h}$ at a temperature of $25 \pm 2{ }^{\circ} \mathrm{C}$ and at a relative humidity of $65 \pm 5 \%$. A standard blue scale was hanged alongside the samples (ISO 105-B02).

The color properties were analyzed using the CIE Colorimetric System [34]. The tristimulus values ( $\mathrm{x}_{\mathrm{r}}$ , $\mathrm{y}_{\mathrm{r}}$ and $\mathrm{z}_{\mathrm{r}}$ ), the relative brightness ( $\mathrm{L}^{*}$ : with values from 100 to 0 representing white to black, respectively), color constants ( $\mathrm{a}^{*}$ : illustrates the red-green value, and $\mathrm{b}^{*}$ : illustrates the yellow-blue value), whiteness index $(\mathrm{W})$, chroma $\left(\mathrm{C}^{*}\right.$ : measure of saturation of color), hue angle $\left(\mathrm{H}^{*}\right)$ and color difference $\left(\Delta \mathrm{E}^{*}\right)$, were performed from the reflectance spectra [34-37].

The absorption coefficient $(\alpha)$, optical band gap energy, extinction coefficient $(\mathrm{K})$, and color strength $(\alpha / S$ : depends on the dye stuff and the substrate) of the untreated and treated silk fabrics under investigation were deduced from the reflectance values in the visible range $400-700 \mathrm{~nm}$ by using the following relations [38-43]:

$$
\begin{aligned}
& \alpha=(1 / \mathrm{d}) \ln \left[(1-\mathrm{R})^{2} / \mathrm{T}\right] \\
& \mathrm{K}=\alpha \lambda / 4 \pi \\
& \alpha / \mathrm{S}=(1-\mathrm{R})^{2} / 2 \mathrm{R}
\end{aligned}
$$

where $\mathrm{R}$ is the reflectance, $\mathrm{T}$ is the transmittance $\left(\approx 10^{-3}\right)$ and $\mathrm{d}$ is the thickness of the sample (about 0.06 $\mathrm{cm})$.

\section{Results and discussion}

\subsection{Optical Parameters}

The reflectance $\%(\mathrm{R} \%)$ spectra in the visible range $(400-700 \mathrm{~nm})$ for unexposed undyed and neem dyed (a) as well as exposed (b) silk fabrics dyed at a temperature of $60^{\circ} \mathrm{C}$ for 60 minutes in dye baths of different $\mathrm{pH}$ values $(3,4,5,6,7,8$ and 9) were shown in Figure 2. It was clear from the figure that the behaviors of the unexposed and exposed dyed silk fabrics completely change in comparison with the undyed sample. 
Unremarkable variation was detected in the reflectance values for the unexposed and exposed undyed samples with wavelength. On other hand, the $\mathrm{R} \%$ values increase markedly with increasing wavelength for all the dyed and exposed silk fabrics and decrease gradually with increasing the $\mathrm{pH}$ values up to 4 and then increase gradually with increasing the $\mathrm{pH}$ values from 5 to 9 . Similar behaviors and trends with more variations were detected for all samples after exposing to artificial day light for $160 \mathrm{~h}$ (Figure $2 \mathrm{~b}$ ).
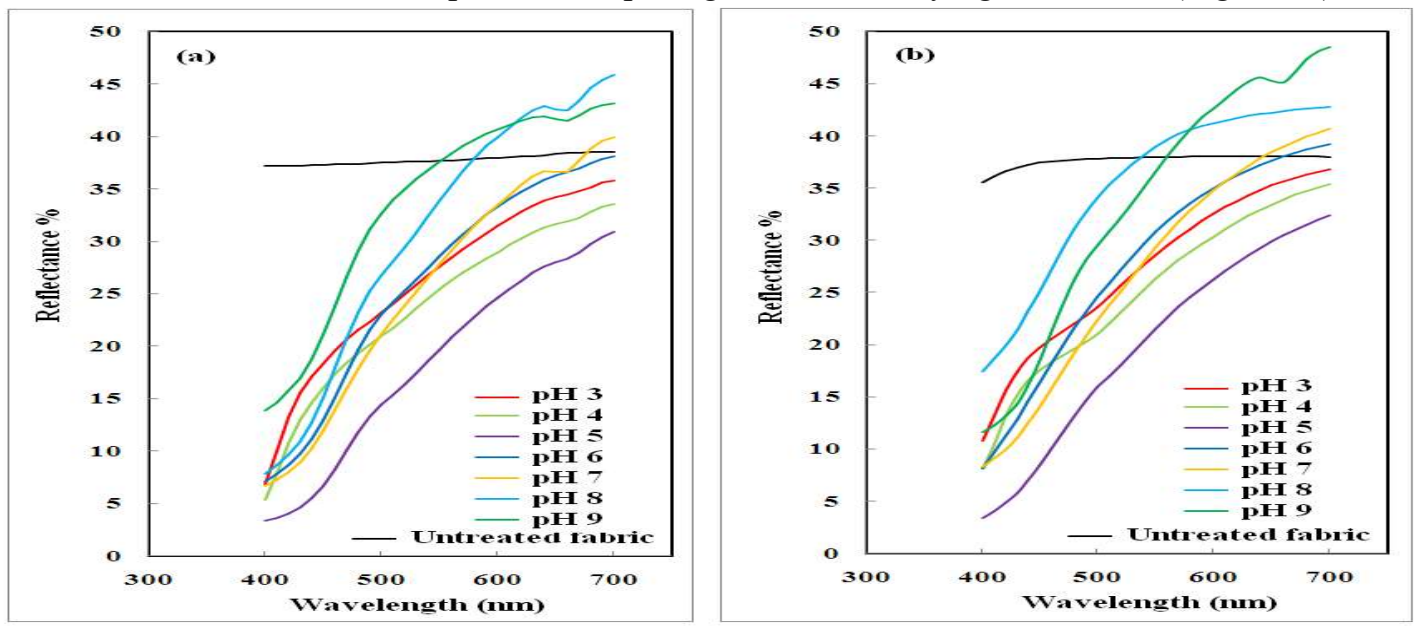

Figure 2. The reflectance $\%$ spectra of untreated and neem dyed silk fabrics with different dye bath $\mathrm{pH}$ values before (a) and after (b) exposure.

Figure 3 shows the reflectance \% spectra in the visible region for unexposed undyed and neem dyed (a) as well as exposed (b) silk fabrics dyed in a medium of $\mathrm{pH}=6$ and time of dying 60 minutes at different dye bath temperatures $\left(20,40,60\right.$, and $\left.80^{\circ} \mathrm{C}\right)$. It was clear from the figure that the behaviors of the unexposed and exposed dyed silk fabrics completely change in comparison with the undyed fabric. No variation was detected in the reflectance values for the unexposed and exposed undyed samples with wavelength. For all the dyed and exposed silk fabrics, markedly increase in the $\mathrm{R} \%$ values was detected by increasing the wavelength while gradually decrease was observed with increasing the dye bath temperature up to $60{ }^{\circ} \mathrm{C}$ for unexposed fabrics. Similar trends with more variations after exposing to artificial day light for $160 \mathrm{~h}$ were detected and the $\mathrm{R} \%$ values reached their minimum values for dye bath temperature of $80^{\circ} \mathrm{C}$ (Figure $3 \mathrm{~b}$ ).
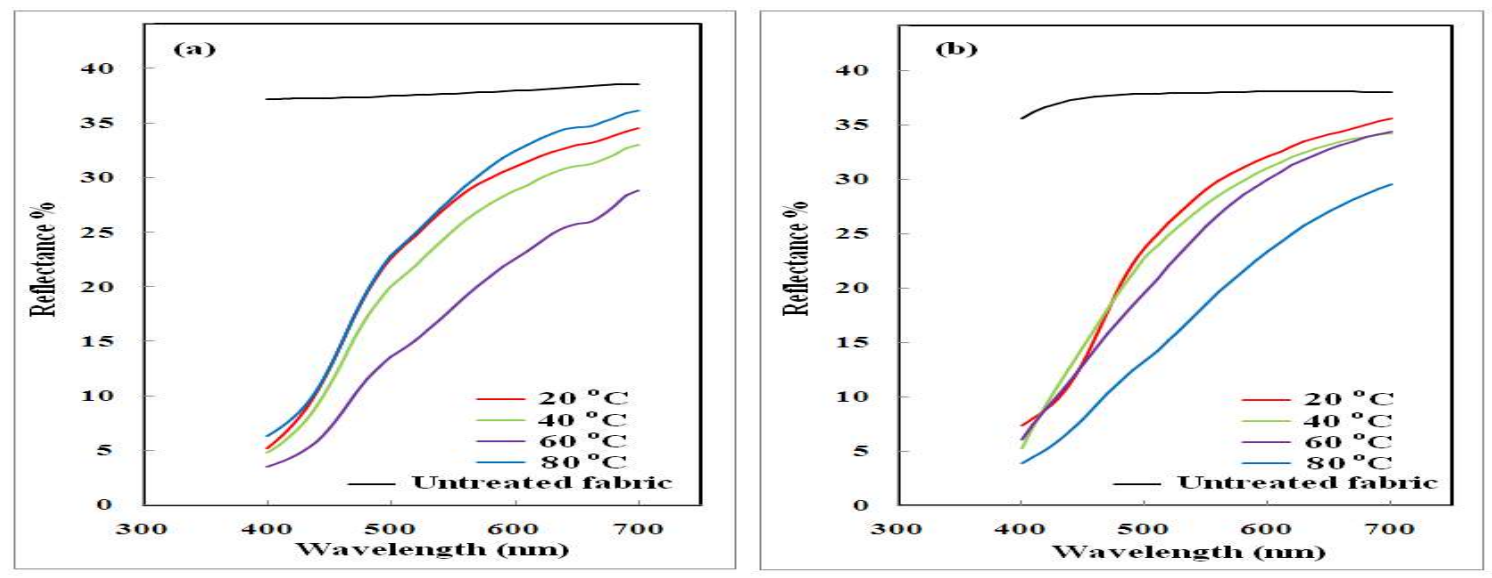

Figure 3. The reflectance $\%$ spectra of untreated and neem dyed silk fabrics with different dye bath temperatures before (a) and after (b) exposure. 
Figure 4 illustrates the R\% spectra for unexposed undyed and neem dyed (a) as well as exposed (b) silk fabrics dyed in a medium of $\mathrm{pH}=6$ and at temperature of $60{ }^{\circ} \mathrm{C}$ in a dye bath for different times $(15,30,45$, and 60 minutes). It was clear from the figure that the behaviors of the unexposed and exposed dyed silk fabrics completely change in comparison with the undyed fabric. No variation was detected in the reflectance values for the unexposed and exposed undyed samples with wavelength. For all the dyed and exposed silk fabrics the R\% values increase markedly with increasing wavelength and decrease gradually with increasing the time of the dye bath up to 60 minutes. Similar behaviors for all samples after exposing to artificial day light for $160 \mathrm{~h}$ with more variations were observed (Figure $4 \mathrm{~b}$ ).
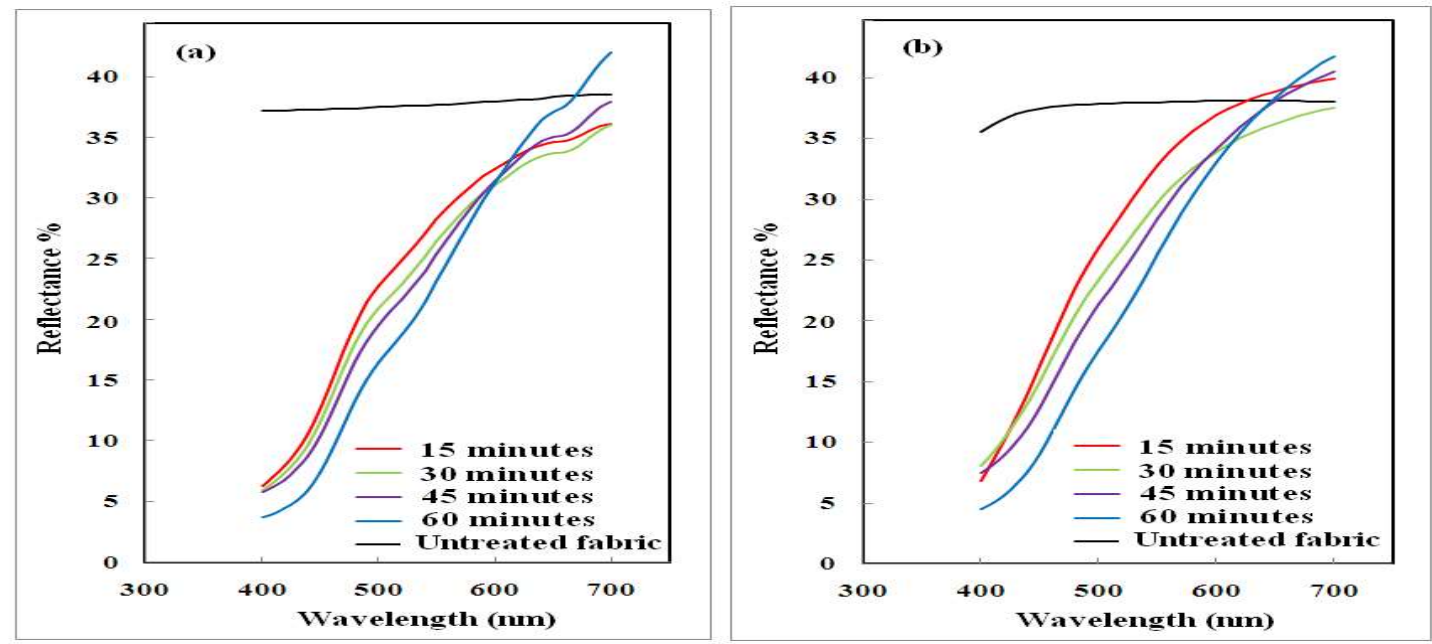

Figure 4. The reflectance $\%$ spectra of untreated and neem dyed silk fabrics with different dye bath times before (a) and after (b) exposure.

From the observed variations, there is a high reflectance (color) change as a function of wavelength by increasing the neem dye bath $\mathrm{pH}$ value, temperature as well as dyeing time. This means that, the dye components role as well as artificial day light was to strength the linkage between the reactive species of the silk fabric chemical groups and their polar groups. As already known, each dye has an optimum dyeing temperature and until that was attaining, dye uptake will continue to increase with increase in temperature as a result of the reduce of the aggregation and increase the amount of dye available to the fiber in dye bath [44].

The variations of the CIE tristimulus values $\left(\mathrm{x}_{\mathrm{r}}, \mathrm{y}_{\mathrm{r}}\right.$ and $\left.\mathrm{z}_{\mathrm{r}}\right)$ for undyed and neem dyed silk fabrics with different dye bath conditions ( $\mathrm{pH}$, temperatures, and dye bath times) before and after exposure to artificial day light for $160 \mathrm{~h}$ were calculated from the values of the reflectance \% spectra (Figures 2-4) and were plotted against wavelength as shown in Figures 5-7, respectively. It was clear from the figures that, the trends of $\mathrm{x}_{\mathrm{r}}$ , $\mathrm{y}_{\mathrm{r}}$ and $\mathrm{z}_{\mathrm{r}}$ for the investigated samples are similar and there are no detectable change in the peak positions either without or with exposure to the artificial day light. Table 1 illustrates the variations in the maximum tristimulus reflectance values at their peak positions for undyed and neem dyed unexposed and exposed silk fabrics under investigation.

Remarkable changes in the tristimulus values were detected either by neem dyeing or by exposing to artificial day light. Also, the tristimulus values at their peak positions for all silk fabric samples with different conditions either the unexposed or exposed to artificial day light were lower than the values of the undyed ones. In addition, the tristimulus reflectance values of the exposed silk fabrics to artificial day light were higher than those of the unexposed ones. 
Table 1. The maximum tristimulus reflectance values $\left(\mathrm{x}_{\mathrm{r}}, \mathrm{y}_{\mathrm{r}}\right.$ and $\left.\mathrm{z}_{\mathrm{r}}\right)$ at their peak positions for untreated and neem dyed silk fabrics with different dyeing conditions before and after exposure to the artificial day light for $160 \mathrm{~h}$.

\begin{tabular}{|c|c|c|c|c|c|}
\hline & & \multicolumn{2}{|c|}{$\mathrm{X}_{\mathrm{r}}$} & \multirow{2}{*}{$\frac{\mathrm{y}_{\mathrm{r}}}{\lambda=560 \mathrm{~nm}}$} & \multirow{2}{*}{$\frac{\mathrm{z}_{\mathrm{r}}}{\lambda=460 \mathrm{~nm}}$} \\
\hline & & $\lambda=450 \mathrm{~nm}$ & $\lambda=600 \mathrm{~nm}$ & & \\
\hline \multicolumn{6}{|c|}{ Unexposed silk fabric samples } \\
\hline Undyed fabric & & 146.0691 & 339.8218 & 371.4584 & 743.6189 \\
\hline \multicolumn{6}{|l|}{ Dyeing conditions } \\
\hline \multirow{7}{*}{$\mathrm{pH}$ values } & 3 & 71.9235 & 281.9448 & 280.1648 & 379.1460 \\
\hline & 4 & 62.6837 & 259.2372 & 258.8370 & 334.6740 \\
\hline & 5 & 27.8137 & 220.4884 & 204.6765 & 159.6600 \\
\hline & 6 & 50.8127 & 298.3868 & 291.9681 & 291.6817 \\
\hline & 7 & 46.9001 & 299.4441 & 286.5828 & 269.2224 \\
\hline & 8 & 60.3529 & 357.6933 & 347.8467 & 346.4456 \\
\hline & 9 & 82.7259 & 364.1624 & 378.0142 & 460.1948 \\
\hline \multirow{4}{*}{$\begin{array}{l}\text { Dyeing temperatures } \\
\left({ }^{\circ} \mathrm{C}\right)\end{array}$} & 20 & 50.2391 & 277.2811 & 281.9401 & 288.3892 \\
\hline & 40 & 44.0677 & 257.7511 & 256.5192 & 252.9632 \\
\hline & 60 & 28.6462 & 201.9363 & 187.7284 & 164.4389 \\
\hline & 80 & 50.1634 & 290.2980 & 287.8464 & 287.9547 \\
\hline \multirow{4}{*}{$\begin{array}{l}\text { Dyeing times } \\
\text { (minutes) }\end{array}$} & 15 & 50.1634 & 290.2980 & 287.8464 & 287.9547 \\
\hline & 30 & 45.9113 & 278.1887 & 271.0575 & 263.5459 \\
\hline & 45 & 41.5291 & 280.9886 & 262.6955 & 238.3909 \\
\hline & 60 & 30.7965 & 279.8431 & 243.9372 & 176.7823 \\
\hline \multicolumn{6}{|c|}{ Exposed silk fabric samples to artificial day light for $160 \mathrm{~h}$} \\
\hline Undyed fabric & & 146.6637 & 340.8764 & 373.810 & 773.1410 \\
\hline \multicolumn{6}{|l|}{ Dyeing conditions } \\
\hline \multirow{7}{*}{$\mathrm{pH}$ values } & 3 & 77.0472 & 291.7374 & 290.2111 & 406.1558 \\
\hline & 4 & 68.5908 & 271.7811 & 268.5609 & 361.5778 \\
\hline & 5 & 32.7294 & 235.0007 & 222.6034 & 191.8321 \\
\hline & 6 & 63.8928 & 313.3940 & 313.3374 & 349.5049 \\
\hline & 7 & 54.6926 & 311.3357 & 301.2330 & 302.6083 \\
\hline & 8 & 98.0903 & 369.1820 & 390.2744 & 523.2345 \\
\hline & 9 & 71.8794 & 381.6749 & 374.2532 & 406.8229 \\
\hline \multirow{4}{*}{$\begin{array}{l}\text { Dyeing temperatures } \\
\left({ }^{\circ} \mathrm{C}\right)\end{array}$} & 20 & 51.3257 & 287.1734 & 293.4586 & 297.2046 \\
\hline & 40 & 57.0024 & 278.0454 & 280.2717 & 315.3457 \\
\hline & 60 & 50.5427 & 268.8280 & 262.9515 & 277.3266 \\
\hline & 80 & 31.0851 & 209.1560 & 192.8246 & 176.0069 \\
\hline \multirow{4}{*}{$\begin{array}{l}\text { Dyeing times } \\
\text { (minutes) }\end{array}$} & 15 & 63.8145 & 330.4866 & 333.1179 & 357.0315 \\
\hline & 30 & 58.8503 & 303.0042 & 303.0831 & 326.2110 \\
\hline & 45 & 50.4252 & 305.6978 & 293.0650 & 282.7304 \\
\hline & 60 & 36.2424 & 295.7645 & 267.4784 & 208.0432 \\
\hline
\end{tabular}


Table 2. The color parameters for undyed and neem dyed silk fabrics with different dyeing conditions before and after exposure to the artificial day light for $160 \mathrm{~h}$.

\begin{tabular}{|c|c|c|c|c|c|c|c|c|}
\hline \multicolumn{9}{|c|}{ Unexposed silk fabric samples } \\
\hline \multirow{2}{*}{ Undyed fabric } & & $\mathrm{L}^{*}$ & $a^{*}$ & $\mathrm{~b}^{*}$ & $\mathrm{~W}$ & $\mathrm{C}^{*}$ & $\mathrm{H}^{*}$ & $\Delta \mathrm{E}^{*}$ \\
\hline & & 75.75 & -0.09 & -0.86 & 33.50 & 0.80 & 101.50 & - \\
\hline \multicolumn{9}{|c|}{ Dyeing conditions } \\
\hline \multirow{7}{*}{$\mathrm{pH}$ values } & 3 & 59.42 & 2.59 & 16.62 & -81.90 & 16.82 & 81.13 & 19.39 \\
\hline & 4 & 57.25 & 2.41 & 17.94 & -96.20 & 18.10 & 82.30 & 21.52 \\
\hline & 5 & 51.29 & 4.05 & 31.36 & -202.20 & 31.62 & 82.64 & 36.26 \\
\hline & 6 & 60.02 & 1.45 & 27.39 & -148.80 & 27.43 & 86.97 & 29.16 \\
\hline & 7 & 59.40 & 3.33 & 29.20 & -160.50 & 29.39 & 83.50 & 31.21 \\
\hline & 8 & 64.59 & 2.11 & 29.83 & -148.00 & 29.76 & 85.93 & 30.76 \\
\hline & 9 & 67.10 & -1.56 & 22.20 & -97.30 & 22.25 & 94.02 & 22.94 \\
\hline \multirow{4}{*}{$\begin{array}{l}\text { Dyeing } \\
\text { temperatures } \\
\left({ }^{\circ} \mathrm{C}\right)\end{array}$} & 20 & 57.10 & -0.83 & 29.80 & -175.10 & 29.81 & 91.59 & 32.30 \\
\hline & 40 & 58.94 & -0.58 & 26.94 & -151.00 & 26.95 & 91.23 & 29.00 \\
\hline & 60 & 56.60 & 0.72 & 27.15 & -159.20 & 27.16 & 88.49 & 29.99 \\
\hline & 80 & 49.51 & 4.21 & 27.72 & -184.90 & 28.04 & 81.37 & 34.03 \\
\hline \multirow{4}{*}{$\begin{array}{l}\text { Dyeing times } \\
\text { (minutes) }\end{array}$} & 15 & 59.55 & 0.61 & 27.51 & -151.60 & 27.51 & 88.72 & 29.37 \\
\hline & 30 & 58.05 & 1.81 & 27.80 & -157.60 & 86.28 & 86.28 & 30.15 \\
\hline & 45 & 57.39 & 3.89 & 29.66 & -169.80 & 29.92 & 82.52 & 32.31 \\
\hline & 60 & 55.64 & 7.50 & 35.90 & -209.80 & 36.67 & 78.20 & 39.27 \\
\hline \multicolumn{9}{|c|}{ Exposed silk fabric samples to artificial day light for $160 \mathrm{~h}$} \\
\hline Undyed fabric & & 67.98 & 0.15 & 0.74 & 33.50 & 0.80 & 101.46 & - \\
\hline \multicolumn{9}{|c|}{ Dyeing conditions } \\
\hline \multirow{7}{*}{$\mathrm{pH}$ values } & 3 & 60.22 & 3.33 & 15.38 & -71.60 & 15.74 & 77.78 & 1.65 \\
\hline & 4 & 58.10 & 4.03 & 16.40 & -83.20 & 16.89 & 76.19 & 2.39 \\
\hline & 5 & 53.16 & 3.71 & 29.62 & -184.60 & 29.85 & 82.86 & 2.57 \\
\hline & 6 & 61.74 & 1.65 & 23.76 & -121.00 & 23.82 & 86.03 & 4.02 \\
\hline & 7 & 60.62 & 3.55 & 26.71 & -141.30 & 26.94 & 82.43 & 2.79 \\
\hline & 8 & 66.61 & 2.26 & 26.58 & -122.40 & 26.68 & 85.14 & 3.77 \\
\hline & 9 & 68.00 & -1.19 & 17.71 & -68.20 & 17.75 & 93.84 & 4.59 \\
\hline \multirow{4}{*}{$\begin{array}{l}\text { Dyeing } \\
\text { temperatures } \\
\left({ }^{\circ} \mathrm{C}\right)\end{array}$} & 20 & 59.97 & -0.77 & 26.69 & -146.10 & 26.70 & 91.65 & 4.19 \\
\hline & 40 & 59.01 & 0.41 & 23.32 & -127.30 & 23.32 & 88.99 & 3.76 \\
\hline & 60 & 57.19 & 2.99 & 24.18 & -136.80 & 24.36 & 82.95 & 3.79 \\
\hline & 80 & 50.01 & 5.53 & 26.45 & -173.30 & 27.02 & 78.19 & 1.90 \\
\hline \multirow{4}{*}{$\begin{array}{l}\text { Dyeing times } \\
\text { (minutes) }\end{array}$} & 15 & 63.17 & 0.68 & 26.11 & -131.40 & 26.12 & 88.51 & 3.88 \\
\hline & 30 & 60.74 & 1.63 & 24.65 & -129.50 & 24.70 & 86.22 & 4.15 \\
\hline & 45 & 59.85 & 4.04 & 27.93 & -150.80 & 28.22 & 81.77 & 3.01 \\
\hline & 60 & 57.46 & 6.88 & 34.16 & -193.70 & 34.84 & 78.62 & 2.59 \\
\hline
\end{tabular}

Parameters such as; the relative brightness, $\mathrm{L}^{*}$, color constants, $\mathrm{a}^{*}$ and $\mathrm{b}^{*}$, whiteness index, W, chroma, $\mathrm{C}^{*}$, and hue angle, $\mathrm{H}^{*}$ as well as the color difference, $\Delta \mathrm{E}^{*}$, were calculated using the CIE Colorimetric System and were tabulated in Table 2 . 

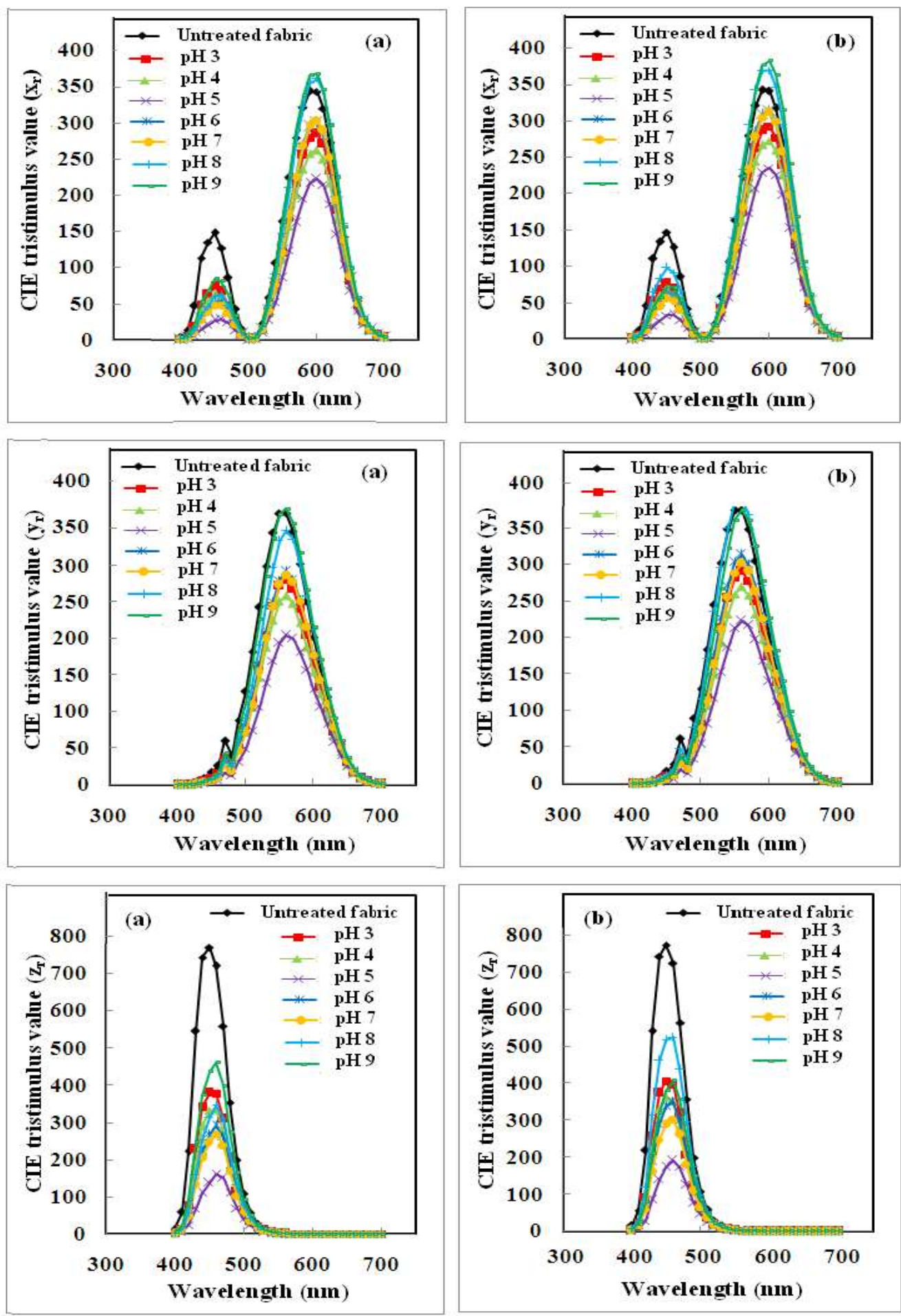

Figure 5. Variations of the CIE tristimulus reflectance values with wavelength for untreated and neem dyed silk fabrics with different dye bath $\mathrm{pH}$ values before (a) and after (b) exposure. 
Dyeing conditions of extracted natural dye from leaves of neem
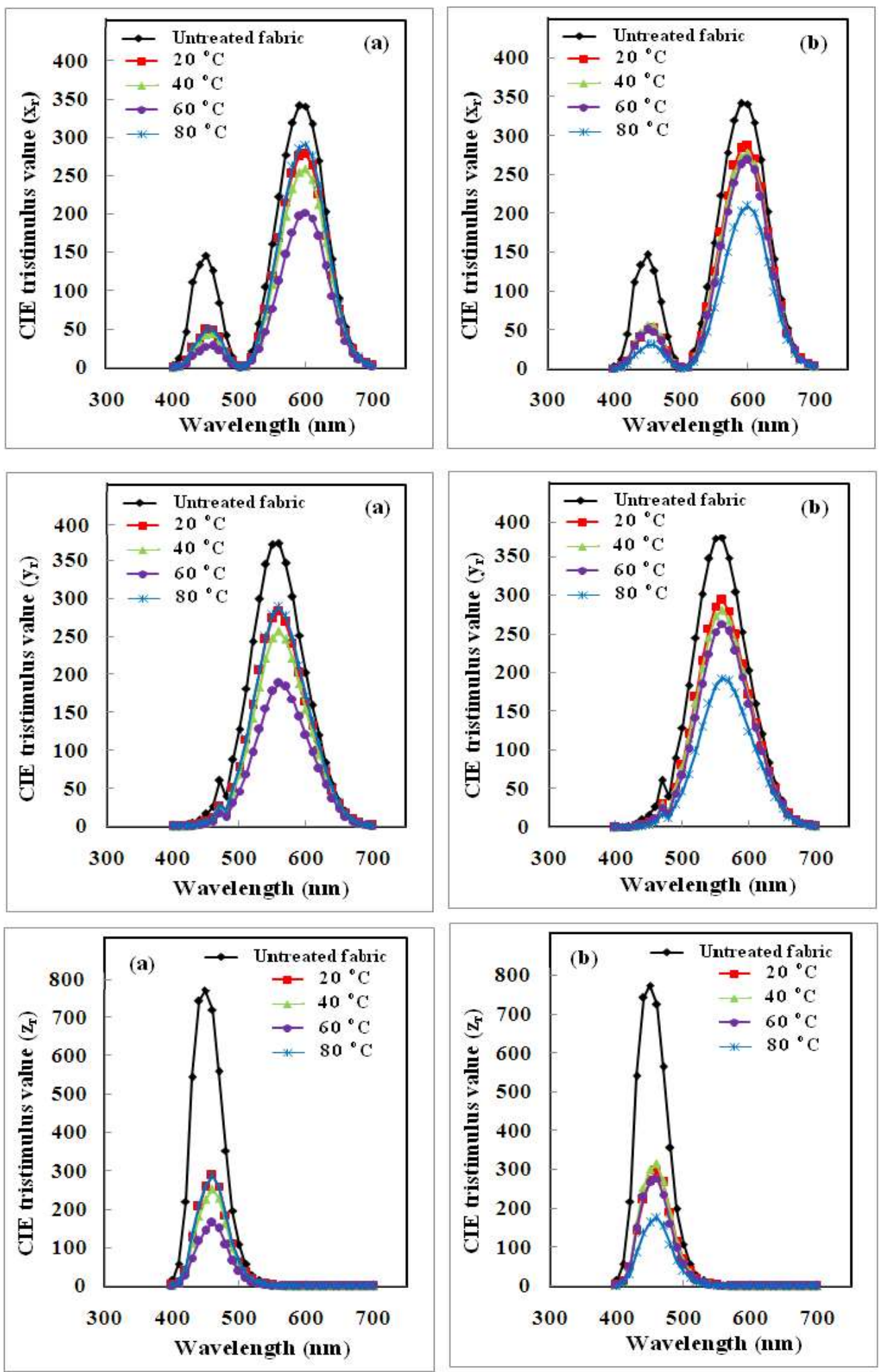

Figure 6. Variations of the CIE tristimulus reflectance values with wavelength for untreated and neem dyed silk fabrics with different dye bath temperatures before (a) and after (b) exposure. 

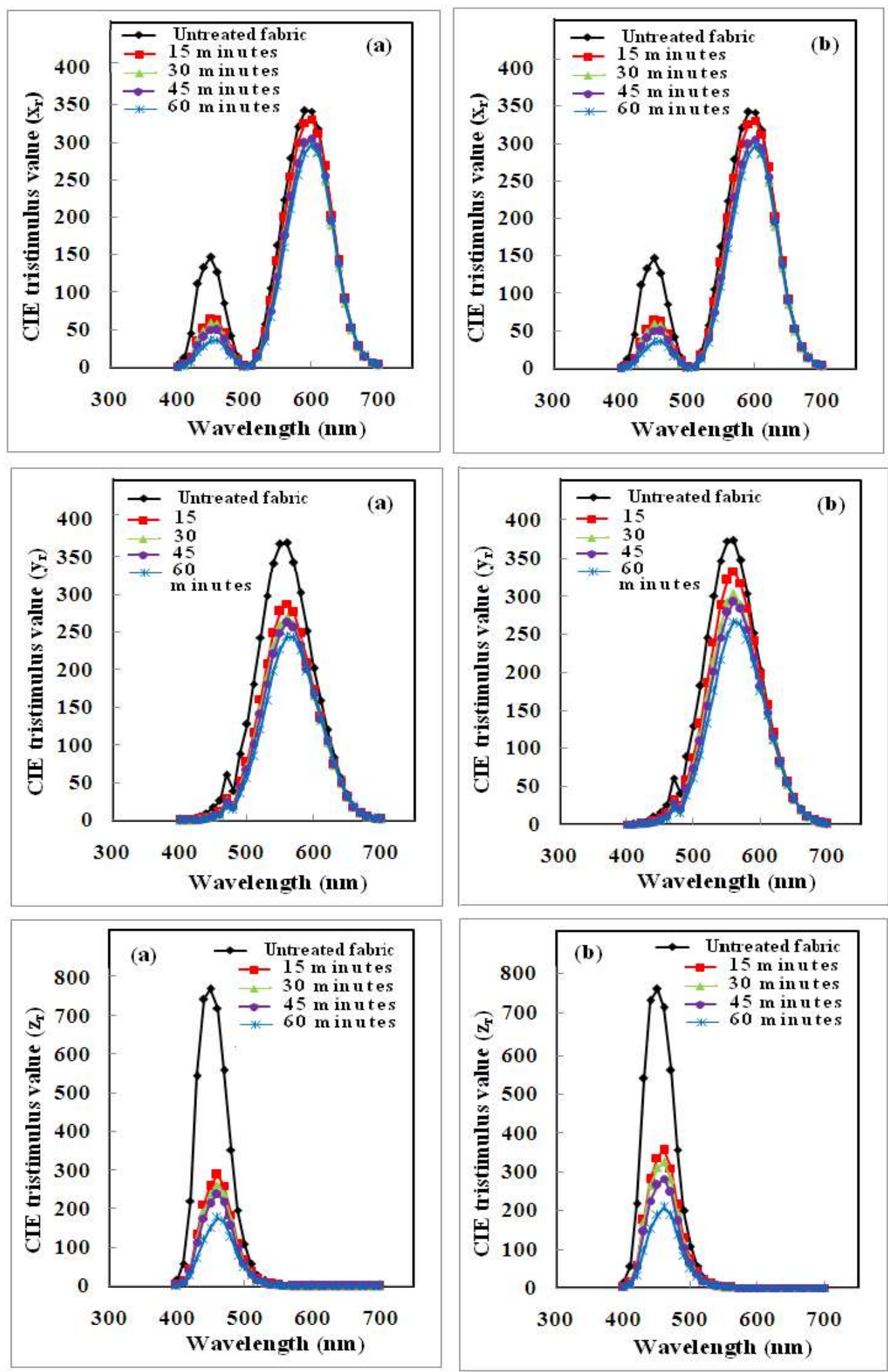

Figure 7. Variations of the CIE tristimulus reflectance values with wavelength for untreated and neem dyed silk fabrics with different dye bath times before (a) and after (b) exposure. 
From Table 2, it was noticed that:

(1) For different dye bath $\mathrm{pH}$ values: The relative brightness, $\mathrm{L}^{*}$, shows decrease in their values with increasing $\mathrm{pH}$ up to 5 for both the unexposed and exposed fabrics and then $\mathrm{L}^{*}$ values increase with increasing $\mathrm{pH}$ values which means that the fabric becomes firstly fader in color and then becomes more brightness. The values of the color constant, $\mathrm{a}^{*}$, increase in their values with increasing $\mathrm{pH}$ up to 5 for both the unexposed and exposed fabrics and then decrease with increasing $\mathrm{pH}$ values which indicates that, there is an increase in red component instead of green component, firstly and then increase in green component instead of red component.

By increasing $\mathrm{pH}$ up to 5 for both the unexposed and exposed fabrics, the values of the color constant, $\mathrm{b}^{*}$, increase and then decrease with further increasing in $\mathrm{pH}$ up to 9 which indicates that the yellow component increases instead of the blue one and then the blue component increases instead of the yellow one, respectively. The detection of the whiteness index, $\mathrm{W}$, values indicated opposite behavior when compared with the color constants, $\mathrm{a}^{*}$ and $\mathrm{b}^{*}$. The obtained decrease in the whiteness index, $\mathrm{W}$, values as well as the variations of the color scales, $\mathrm{C}^{*}$ and $\mathrm{H}^{*}$, and color difference, $\Delta \mathrm{E}$, indicated there are variations in color difference between the undyed and the neem dyed fabrics were produced due to the presence of different neem dye bath $\mathrm{pH}$ and/or exposure to artificial day light.

(2) For different dye bath temperatures and dyeing times: The values of the relative brightness, $\mathrm{L}^{*}$, decrease with increasing temperature up to $80{ }^{\circ} \mathrm{C}$ or dyeing times up to 60 minutes for both the unexposed and exposed fabrics which indicates that the fabric becomes fader in color. The values $\mathrm{a}^{*}$ and $\mathrm{b}^{*}$ increase with increasing either temperature or dyeing times for both the unexposed and exposed fabrics which mean that the red and yellow components increases instead of the green and blue components, respectively. The variation in the whiteness index, $\mathrm{W}$, values has opposite trend when compared with that of the color constants. The detectable variations in the whiteness index, the color scales and the color difference values indicate that color difference between the undyed and the neem dyed fabrics were caused due to the presence of different neem dye bath temperatures or dyeing times and/or exposure to artificial day light.

The observed changes in the color parameters with the increase in the different conditions of dye bath may be attributed to changes in the molecular configuration of the fabric were produced and also new doping centers were formed due to the change in the physical bonds. Therefore, the obtained results of the color parameters improved the optical properties of the fabrics.

\subsection{Absorption Parameters}

The absorption coefficients $(\alpha)$ of the undyed as well as the unexposed (a) and exposed to artificial day light for $160 \mathrm{~h}$ (b), silk fabrics dyed with different dyed conditions ( $\mathrm{pH}$ values, dye bath temperatures, and dye bath times) were calculated in the wavelength from 400 to $700 \mathrm{~nm}$ (i.e., photon energy from 3.10 to 1.77 eV) by using Eq. 1 from the reflectance \% spectra (Figs. 2-4) and were shown in Figs. 8-10, respectively. From the figures, by increasing the wavelength, remarkable decrease in the absorption coefficient values were observed for all samples. As shown in Figure8, the absorption coefficient values for both the unexposed and exposed samples increase with increasing the $\mathrm{pH}$ values of the neem dye bath up to 5 through the whole wavelength followed by fluctuated variations with increasing the $\mathrm{pH}$ values up to 9. As shown in Figure9, gradual increase in the absorption coefficient values for both the unexposed (up to $60{ }^{\circ} \mathrm{C}$ ) and exposed samples to artificial day light for $160 \mathrm{~h}$ (up to $80^{\circ} \mathrm{C}$ ) with increasing the neem dye bath temperatures through the whole wavelength. As observed from Figure10, gradual increase in the absorption coefficient values for both the unexposed and exposed samples with increasing the neem dye bath times up to 60 minutes through the whole range of wavelength. 

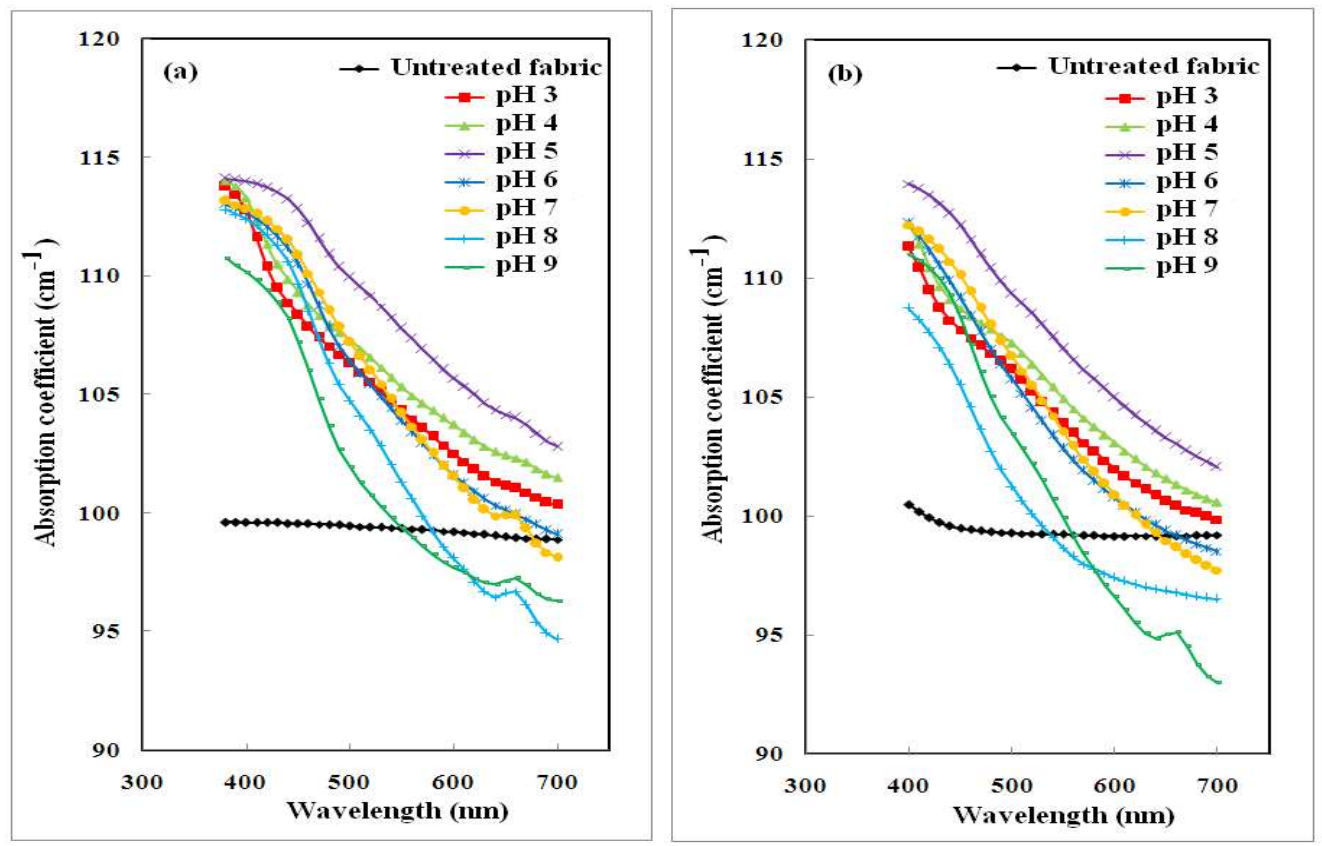

Figure 8. Plots of the absorption coefficient values of undyed as well as neem dyed silk fabrics with different dye bath $\mathrm{pH}$ values before (a) and after (b) exposure.
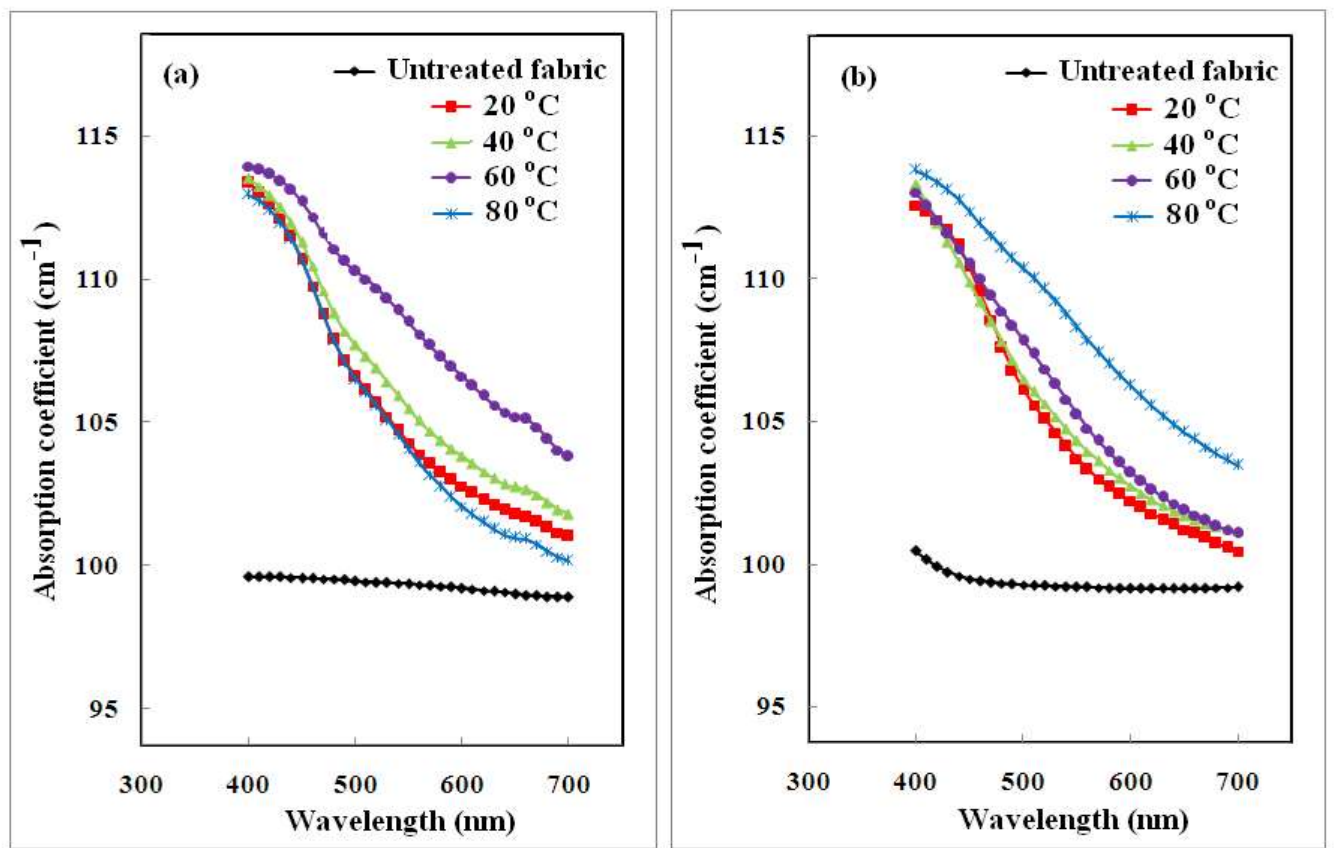

Figure 9. Plots of the absorption coefficient values of undyed as well as neem dyed silk fabrics with different dye bath temperatures before (a) and after (b) exposure. 
Dyeing conditions of extracted natural dye from leaves of neem
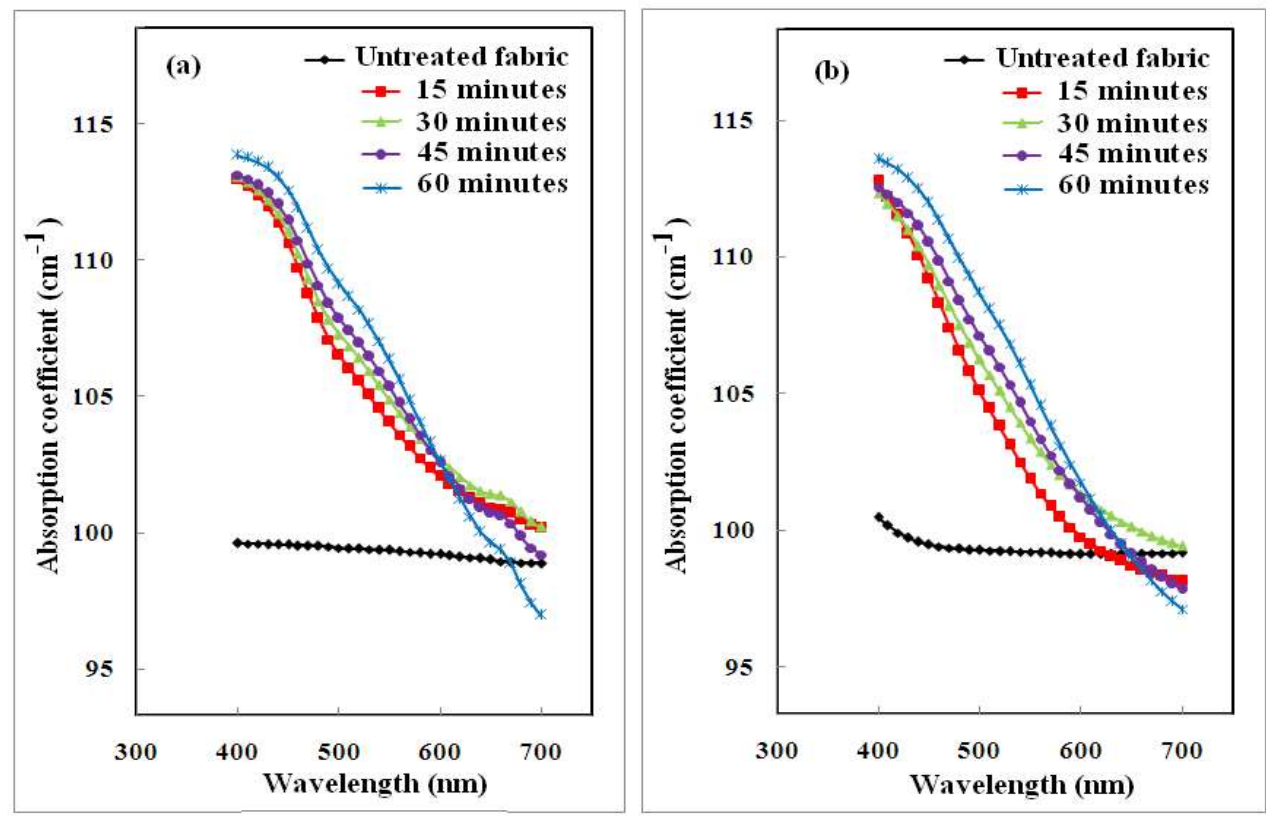

Figure 10. Plots of the absorption coefficient values of undyed as well as neem dyed silk fabrics with different dye bath times before (a) and after (b) exposure.

The detected increase in the absorption coefficient values by increasing the neem dye bath $\mathrm{pH}$ values up to 5 , temperatures up to $80{ }^{\circ} \mathrm{C}$ or times up to 60 minutes and exposure to the artificial day light may be attributed to formation of free radicals and new color centers due to the change in the chemical bonds between the fabric and the dye condition and, also, form other molecular species as a result of the degradation process. In addition, the dye components role was to strength the linkage between the reactive species of the silk fabric chemical groups and their polar groups. These obtained results are in agreement with that previously reported in the literature [45-47].
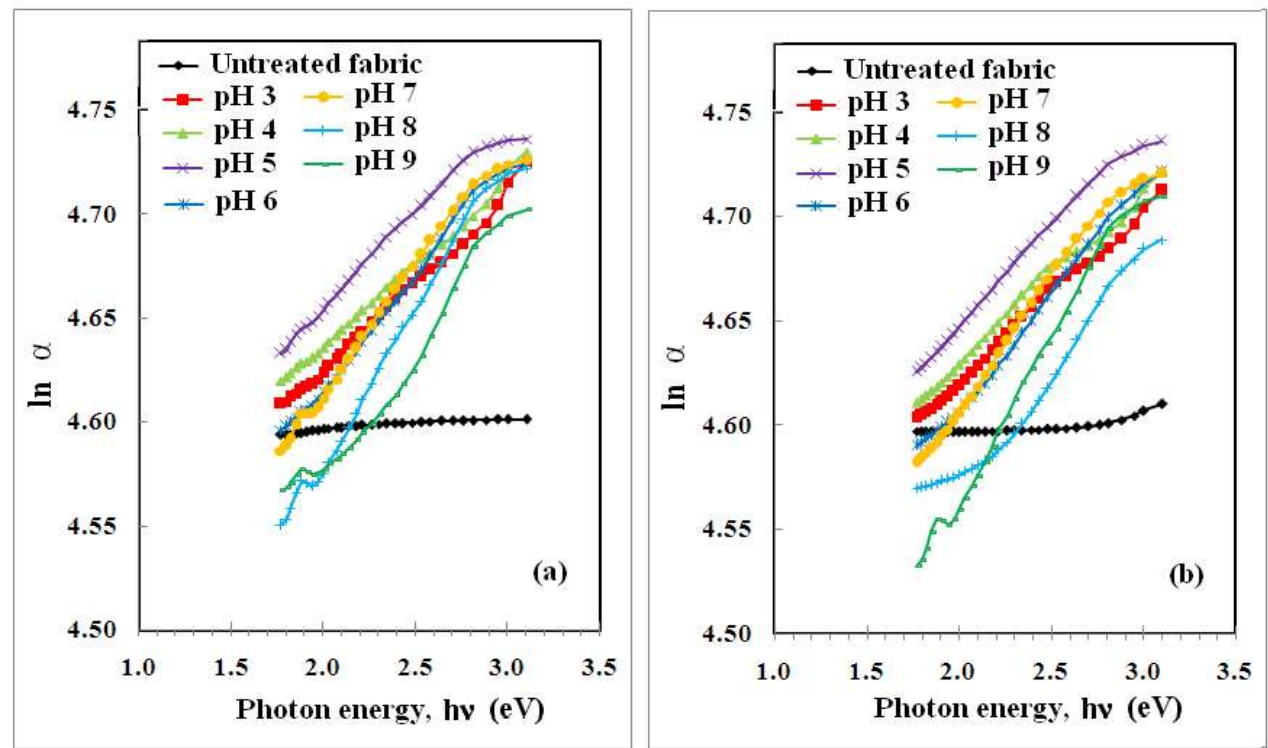

Figure 11. Variations of $\ell \mathrm{n} \alpha$ with $\mathrm{h} v$ for undyed and neem dyed silk fabrics with different dye bath $\mathrm{pH}$ values before (a) and after (b) exposure. 
Figures 11-13, respectively, represent the variation of $\ell \mathrm{n} \alpha$ with photon energy $(\mathrm{h} v)$ for undyed and neem dyed silk fabrics with different dye bath conditions ( $\mathrm{pH}$ values, dye bath temperatures, and dye bath times) before (a) and after (b) exposure to artificial day light for $160 \mathrm{~h}$.
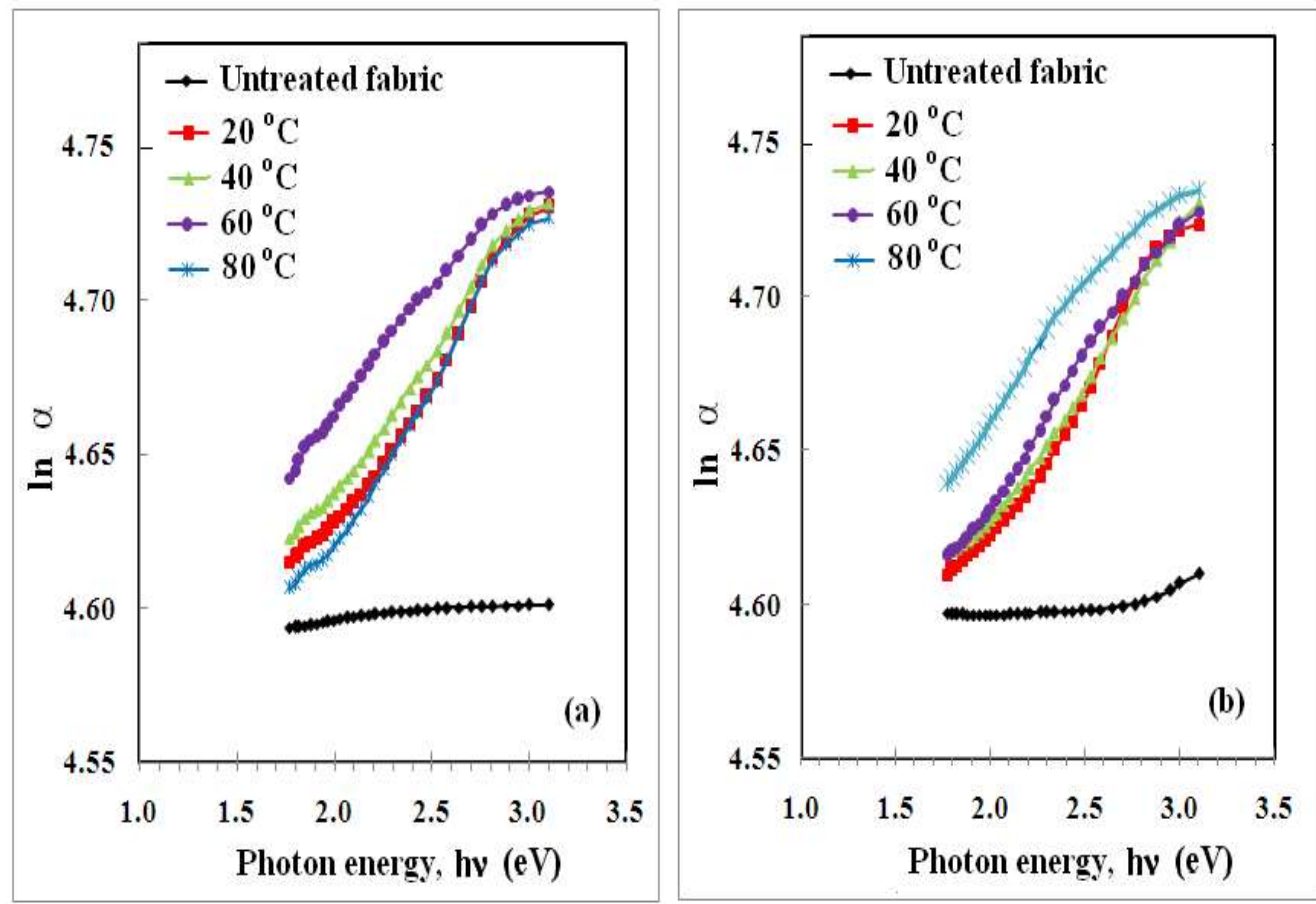

Figure 12. Variations of $\ell \mathrm{n} \alpha$ with $\mathrm{h} v$ for undyed and neem dyed silk fabrics with different dye bath temperatures before (a) and after (b) exposure.
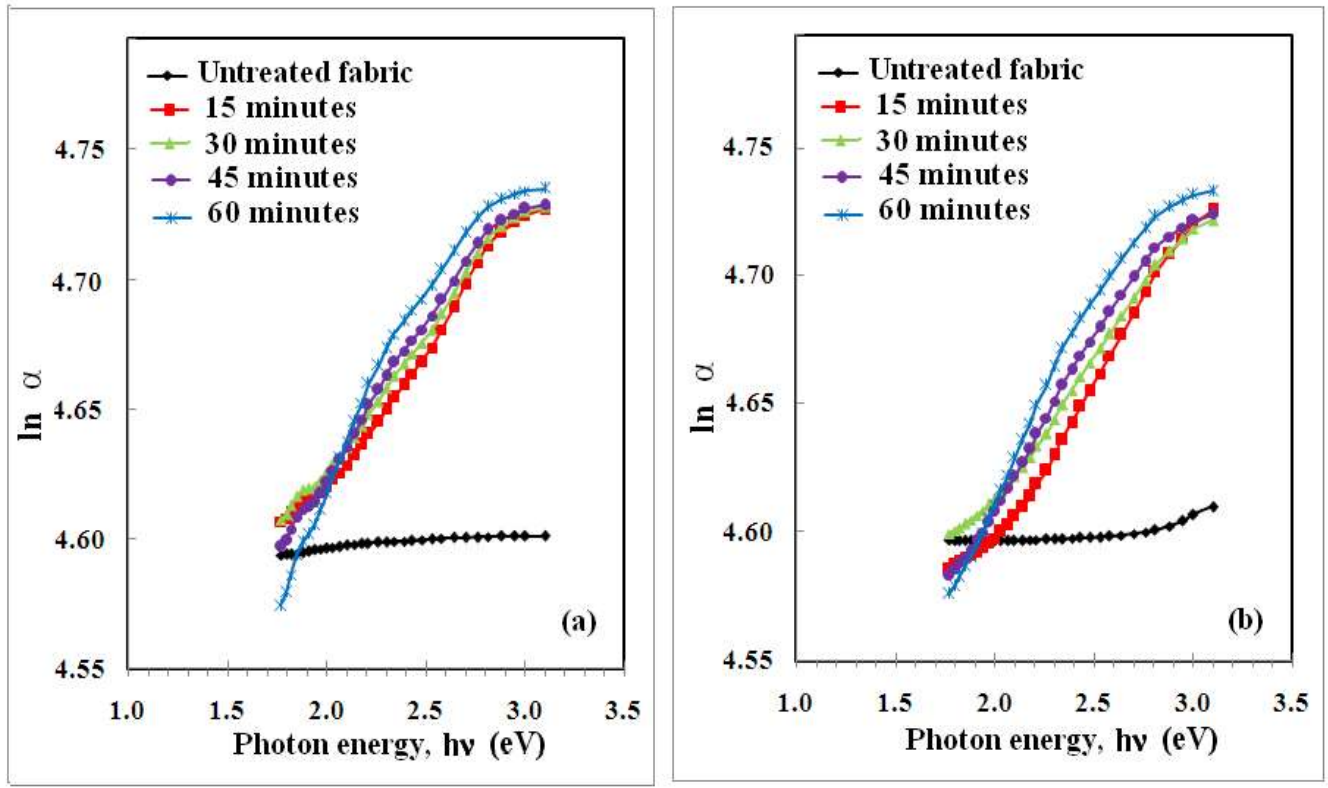

Figure 13. Variations of $\ell \mathrm{n} \alpha$ with $\mathrm{h} v$ for undyed and neem dyed silk fabrics with different dye bath times before (a) and after (b) exposure.

It was clear from the figures that, each curve could not be represented by straight lines relation in the whole photon energy range under study $(3.10-1.77 \mathrm{eV})$ which means that the absorption does not verify 
Urbach rule for inter-band transitions [41]. On other hand, as observed from Figs. 12b and $13 \mathrm{~b}$ that the variations between $\ln \alpha$ and $h v$ are more regular with increasing the neem dye bath temperatures and times for the exposed samples which may due to the change in the total number available states caused by exposing to the artificial light according to the compromise between the degradation and/or cross-linking processes and the variation in the internal fields due to the interaction between neem and silk fabrics chemical groups in different dye bath conditions $[48,49]$.

The optical energy gaps $\left(\mathrm{E}_{\mathrm{g}}\right)$ of the unexposed and exposed silk samples under investigation were calculated from the absorption coefficients data from the power part according to Tauc's model as [41,43]:

$$
\alpha h v=B\left(h v-E_{g}\right)^{n}
$$

where B covers the range $10^{5}-10^{6}\left(\mathrm{~cm} . \mathrm{eV}^{-1}\right.$ calculated from the slope of Tauc's edge which represents the band tail parameter and $\mathrm{n}$ is the electronic transition responsible type for absorption $(n=1 / 2$ for the allowed direct transition, or $\mathrm{n}=2$ for the indirect transition, respectively). Figs. 14-16 show the dependence of $(\alpha \mathrm{h} v)^{2}$ on photon energy (hv) for undyed and neem dyed silk fabrics with different dye bath conditions ( $\mathrm{pH}$ values, temperatures and times) before (a) and after (b) exposure to artificial day light for $160 \mathrm{~h}$, respectively. Figs. 17-19 illustrate the variations of $(\alpha \mathrm{hv})^{1 / 2}$ with photon energy (hv) for undyed and neem dyed silk fabrics with different dye bath $\mathrm{pH}$ values, temperatures and times before (a) and after (b) exposure to artificial day light, respectively. It was noticed from the figures that, all samples under investigation represent same behaviors like that of their absorption coefficients trends under the same dye bath conditions. As observed from Figs. $15 \mathrm{~b}, 16 \mathrm{~b}, 18 \mathrm{~b}$ and $19 \mathrm{~b}$ that the dependence of $(\alpha \mathrm{h} v)^{2}$ and $(\alpha \mathrm{hv})^{1 / 2}$ on $\mathrm{h} v$ are more regular with increasing the neem dye bath temperatures and times for the exposed samples which may due to [48,49]: (1) the change in the total number available states caused by exposing to the artificial light according to the compromise between the degradation and/or cross-linking processes; (2) the variation in the internal fields due to the interaction between neem and silk fabrics chemical groups in different dye bath conditions; and (3) the change in molecular configuration which leads to structural variations.
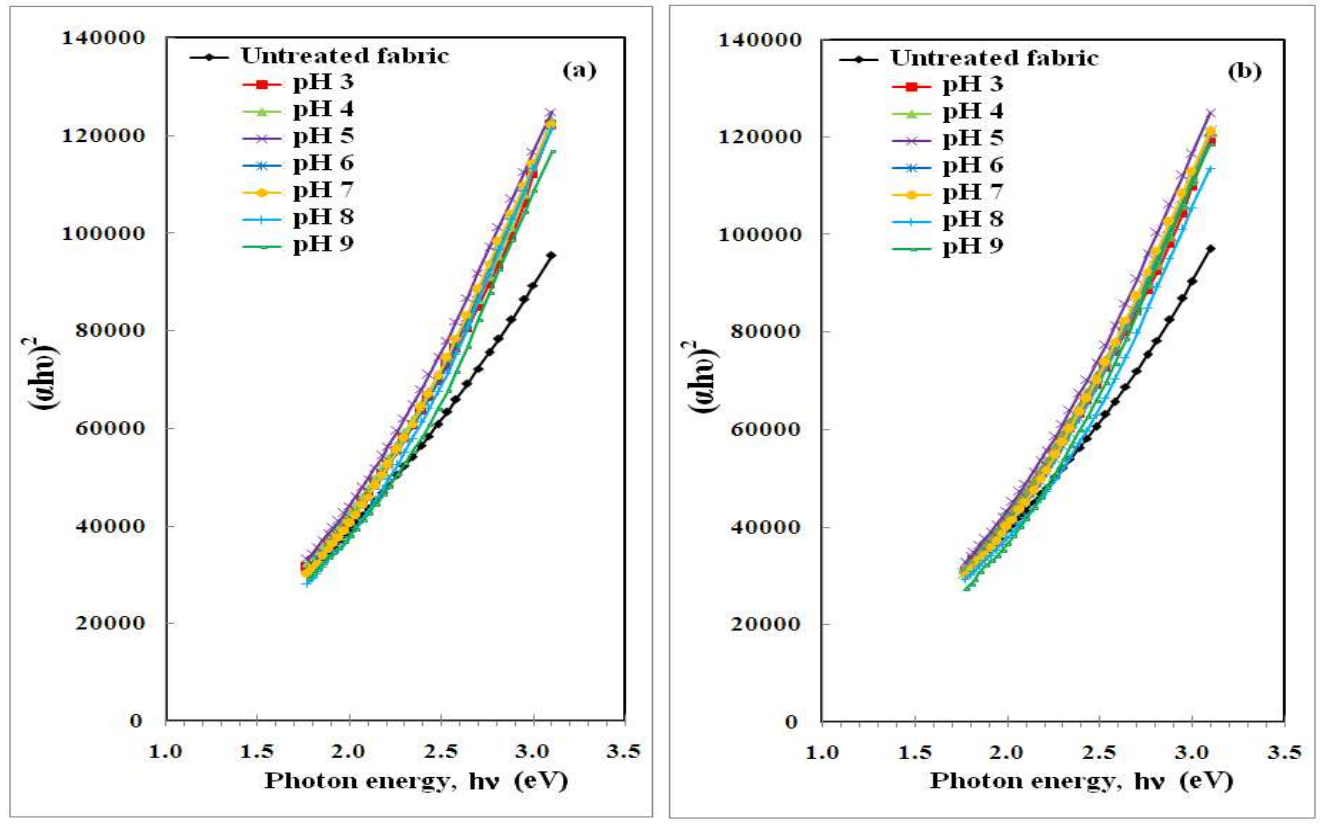

Figure 14. Variations of $(\alpha h v)^{2}$ with photon energy (hv) for undyed and neem dyed silk fabrics with different dye bath $\mathrm{pH}$ values before (a) and after (b) exposure. 

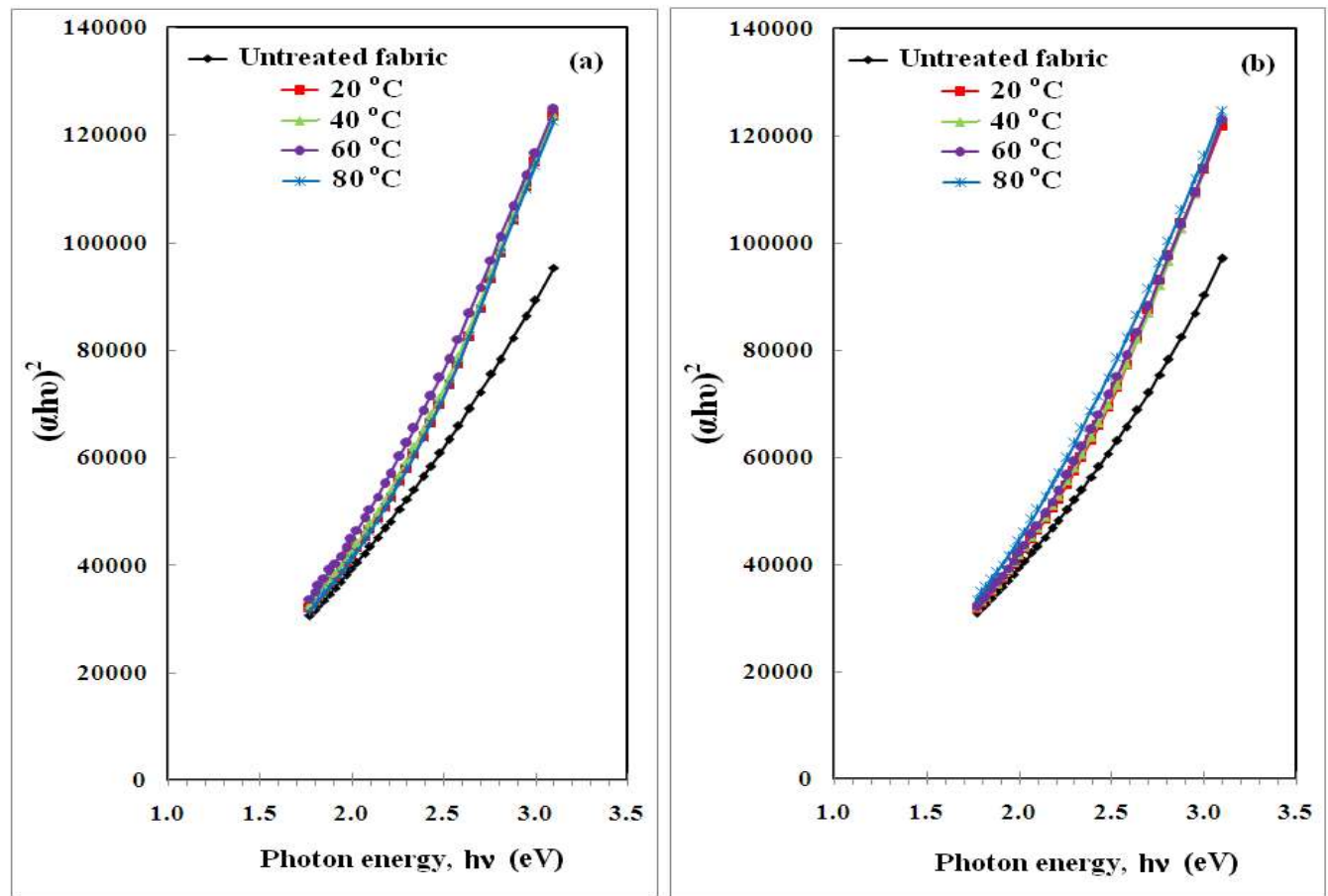

Figure 15. Variations of $(\alpha h v)^{2}$ with photon energy $(h v)$ for undyed and neem dyed silk fabrics with different dye bath temperatures before (a) and after (b) exposure.
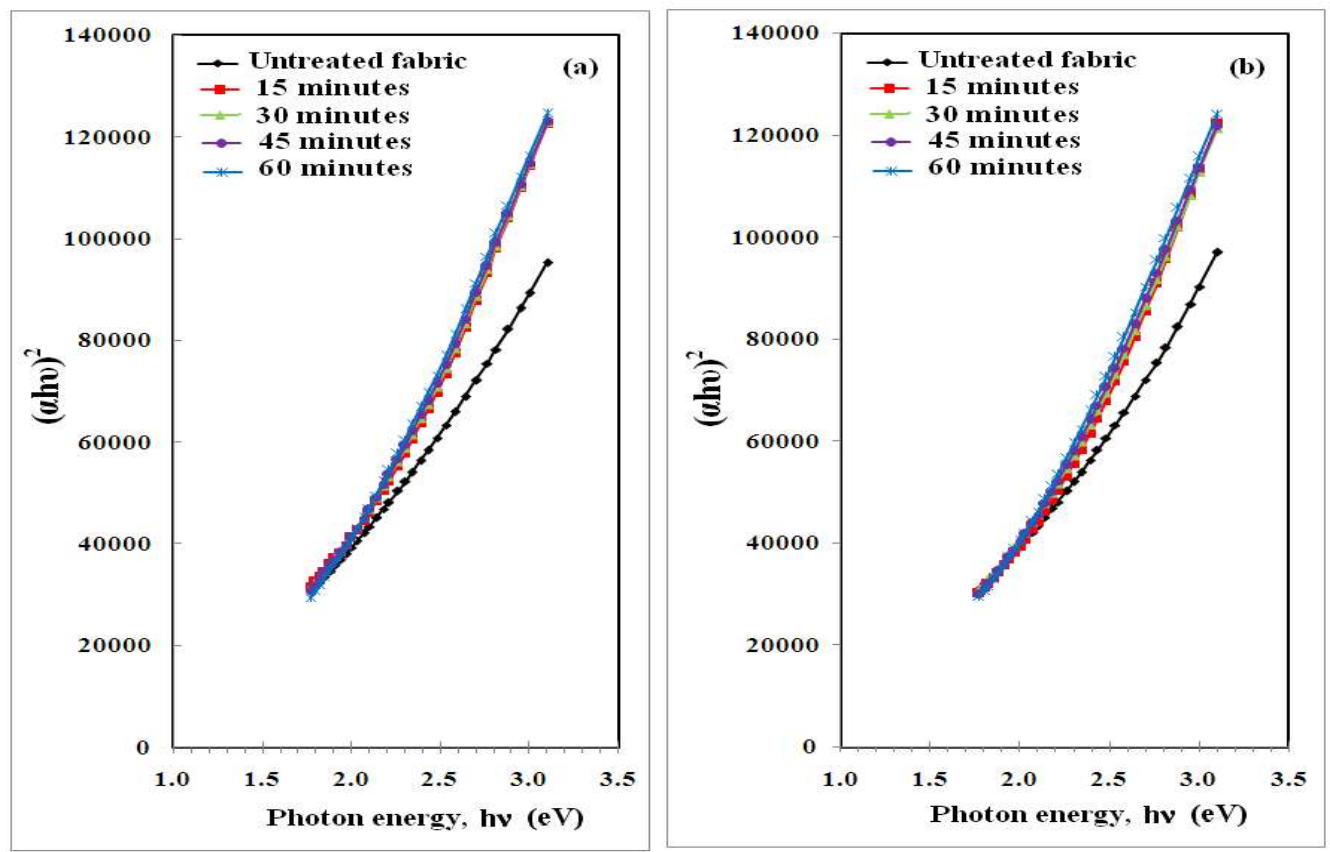

Figure 16. Variations of $(\alpha h v)^{2}$ with photon energy (hv) for undyed and neem dyed silk fabrics with different dye bath times before (a) and after (b) exposure. 
Dyeing conditions of extracted natural dye from leaves of neem
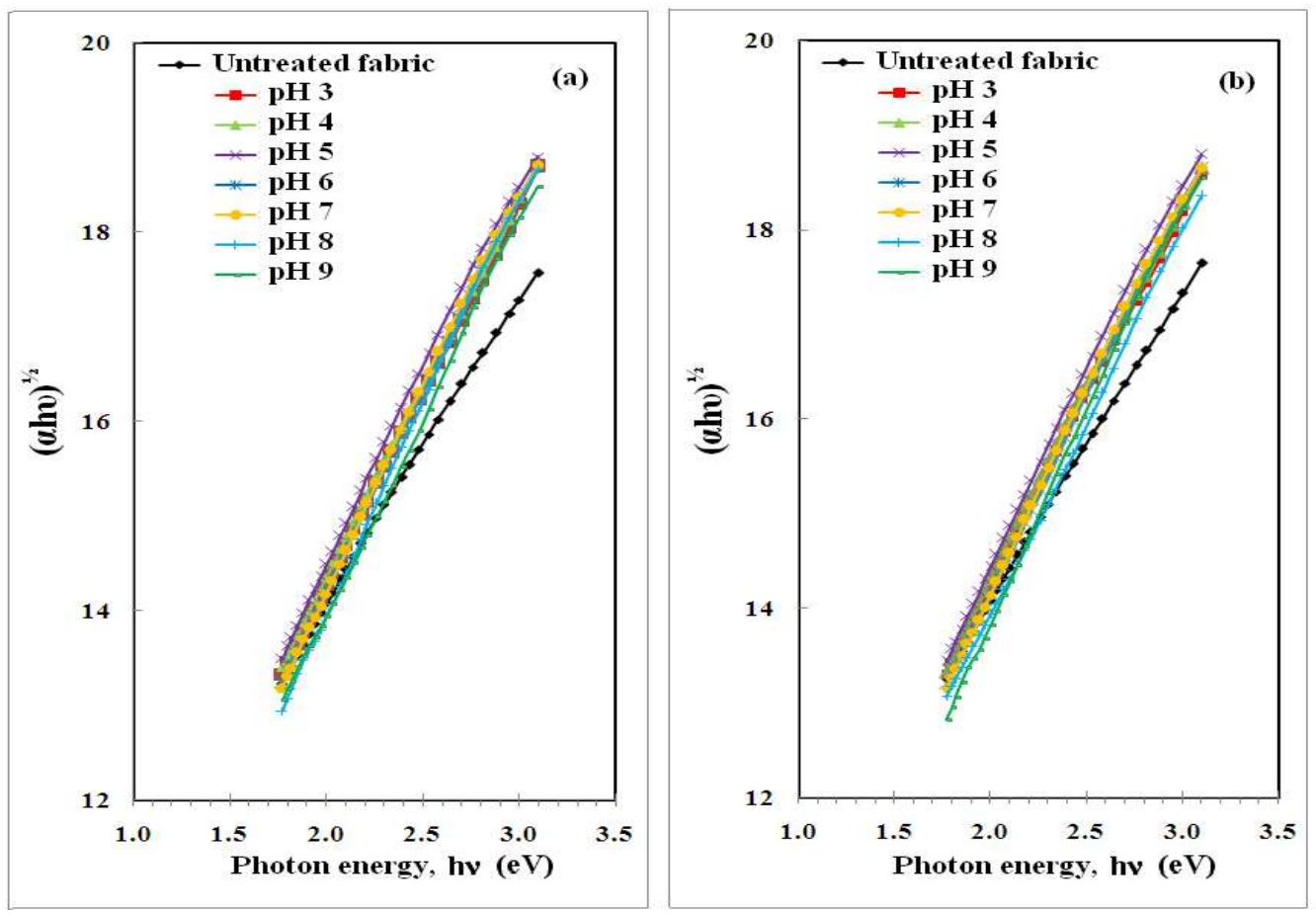

Figure 17. Variations of $(\alpha h v)^{1 / 2}$ with photon energy $(h v)$ for undyed and neem dyed silk fabrics with different dye bath $\mathrm{pH}$ values before (a) and after (b) exposure.
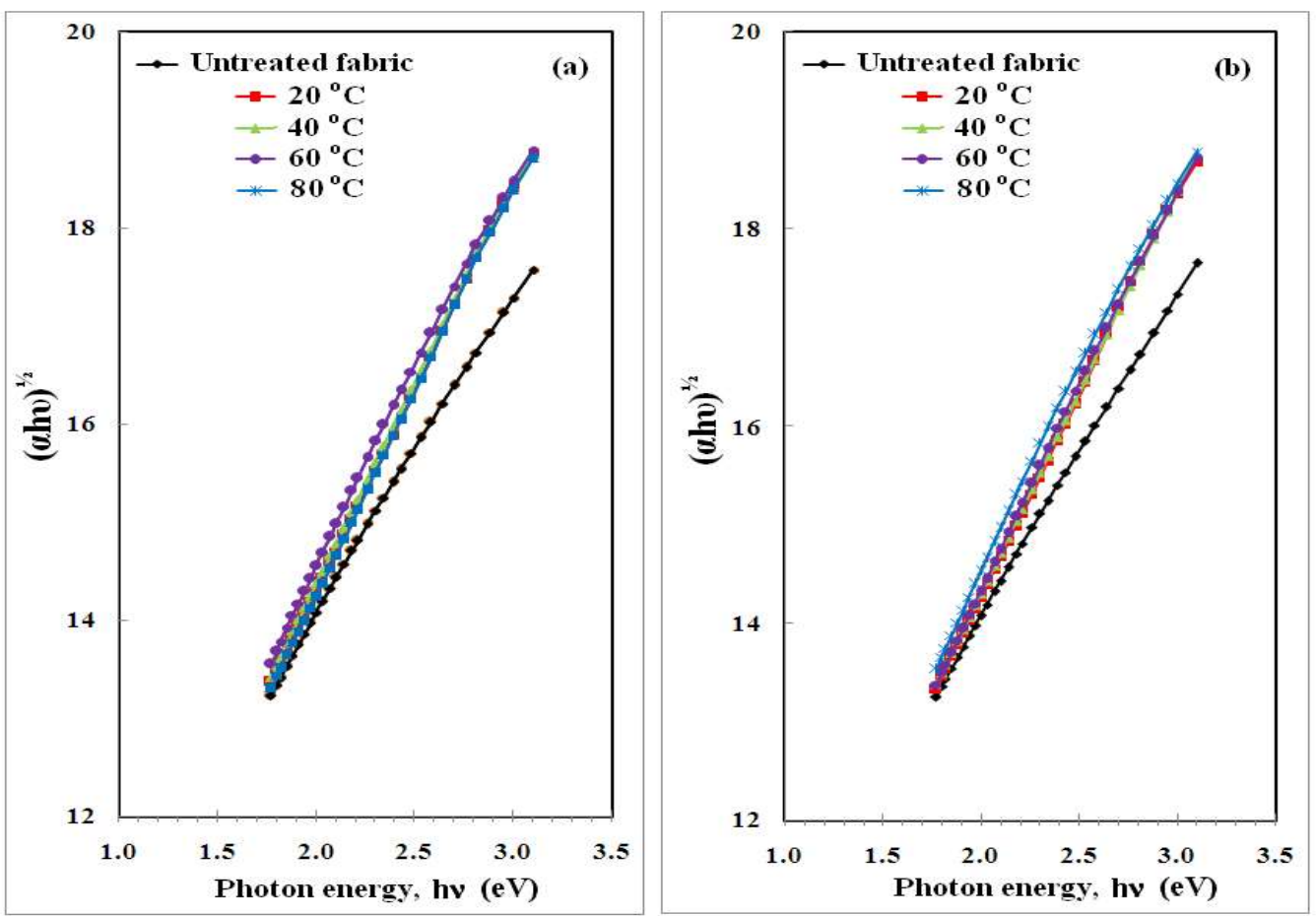

Figure 18. Variations of $(\alpha h v)^{1 / 2}$ with photon energy $(h v)$ for undyed and neem dyed silk fabrics with different dye bath temperatures before (a) and after (b) exposure. 

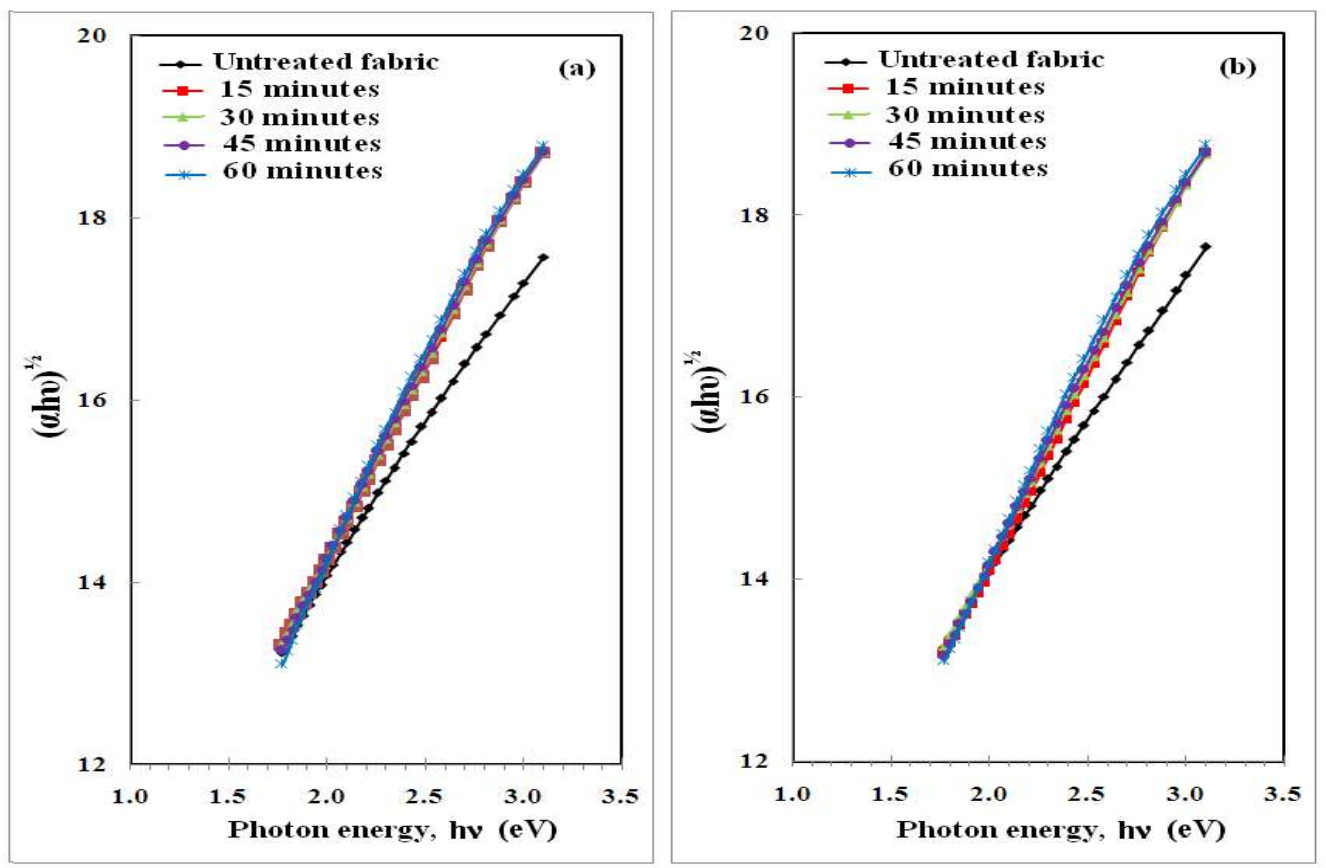

Figure 19. Variations of $(\alpha h v)^{1 / 2}$ with photon energy $(h v)$ for undyed and neem dyed silk fabrics with different dye bath times before (a) and after (b) exposure.

From Figs. 14-16, the values of the allowed direct energy gap $\left(E_{d}\right)$ were calculated by extending the linear parts of the curves to zero absorption and tabulated in Table 3. From the table, in comparison with the unexposed undyed fabric, the $E_{d}$ values were increased with dye bath conditions. The $E_{d}$ values of the dyed fabrics exposed to the artificial light were smaller than that of the undyed one. These variations indicate that the values of $E_{d}$ show the dependence on the composite and creation of localized states in the band gap. Moreover, the detected change in the optical energy gap $\left(E_{d}\right)$ may be attributed to the change in molecular configuration and formation of free radicals due to rupture of the bonds and then structural changes were occurred $[46,48,49]$. Furthermore, the data noticed that, unremarkable change in the structure of silk fabrics were detected when the neem dye bath conditions are: $\mathrm{pH}=5$, at $\mathrm{T}=60^{\circ} \mathrm{C}$ and for dyeing time $=60$ minutes for the unexposed silk fabric, and neem dye bath conditions of $\mathrm{pH}=5$, at $\mathrm{T}=80{ }^{\circ} \mathrm{C}$ and for dyeing time $=60$ minutes for the exposed silk fabric to artificial day light for $160 \mathrm{~h}$.

The variations in the extinction coefficients (K) (calculated by using Eq. 2 [42]) as functions of wavelength for undyed and neem dyed silk fabrics with different dye bath conditions $(\mathrm{pH}$ values, temperatures and times) before (a) and after (b) exposure to artificial day light for $160 \mathrm{~h}$ were illustrated in Figures 20-22, respectively. As known, the extinction coefficient represented the photonic material and the properties of the material to light, it was noticed that, similar trends of the extinction coefficient for all samples under different conditions were similar observed and their values were in the order $10^{-4}$. Moreover, the increase in the extinction coefficient values either with increasing the neem dye bath temperatures and/or times without or with exposure to artificial light illustrates that fraction of light was lost due to scattering which indicates that at room temperature silk fabric was considered to be an insulating material as reported by Pankove [50]. 
Table 3. Values of the direct energy gap $\left(E_{d}\right)$ for undyed and neem dyed silk fabrics with different dyeing conditions before and after exposure to the artificial day light for $160 \mathrm{~h}$.

\begin{tabular}{|c|c|c|c|}
\hline \multirow{2}{*}{\multicolumn{2}{|c|}{ Unoynoced silk fohric camplec }} & \multicolumn{2}{|c|}{ Direct energy gap $\left(\mathrm{E}_{\mathrm{d}}\right)(\mathrm{eV})$} \\
\hline & & $\mathrm{E}_{\mathrm{d}}(\mathrm{eV})$ & $\Delta\left(\mathrm{E}_{\mathrm{d}}\right) \%$ \\
\hline \multicolumn{4}{|c|}{ Unexposed silk fabric samples } \\
\hline \multicolumn{2}{|c|}{ Undyed fabric } & 1.564 & - \\
\hline \multicolumn{4}{|c|}{ Dyeing conditions } \\
\hline \multirow{7}{*}{$\mathrm{pH}$ values } & 3 & 1.863 & 19.1 \\
\hline & 4 & 1.806 & 15.5 \\
\hline & 5 & 1.599 & 2.2 \\
\hline & 6 & 1.658 & 6.0 \\
\hline & 7 & 1.652 & 5.6 \\
\hline & 8 & 1.672 & 6.9 \\
\hline & 9 & 1.708 & 9.2 \\
\hline \multirow{4}{*}{$\begin{array}{l}\text { Dyeing temperatures } \\
\left({ }^{\circ} \mathrm{C}\right)\end{array}$} & 20 & 1.683 & 8.2 \\
\hline & 40 & 1.661 & 6.2 \\
\hline & 60 & 1.609 & 2.9 \\
\hline & 80 & 1.655 & 5.8 \\
\hline \multirow{4}{*}{$\begin{array}{l}\text { Dyeing times } \\
\text { (minutes) }\end{array}$} & 15 & 1.655 & 5.8 \\
\hline & 30 & 1.643 & 5.1 \\
\hline & 45 & 1.621 & 3.6 \\
\hline & 60 & 1.595 & 2.0 \\
\hline \multicolumn{4}{|c|}{ Exposed silk fabric samples to artificial day light for $160 \mathrm{~h}$} \\
\hline \multicolumn{2}{|l|}{ Undyed fabric } & 2.078 & - \\
\hline \multicolumn{4}{|l|}{ Dyeing conditions } \\
\hline \multirow{7}{*}{$\mathrm{pH}$ values } & 3 & 1.830 & 32.9 \\
\hline & 4 & 1.784 & 14.1 \\
\hline & 5 & 1.660 & 6.1 \\
\hline & 6 & 1.797 & 14.9 \\
\hline & 7 & 1.681 & 7.5 \\
\hline & 8 & 1.786 & 14.2 \\
\hline & 9 & 1.660 & 6.1 \\
\hline \multirow{4}{*}{$\begin{array}{l}\text { Dyeing temperatures } \\
\left({ }^{\circ} \mathrm{C}\right)\end{array}$} & 20 & 1.643 & 5.1 \\
\hline & 40 & 1.812 & 15.9 \\
\hline & 60 & 1.744 & 11.5 \\
\hline & 80 & 1.633 & 4.4 \\
\hline \multirow{4}{*}{$\begin{array}{l}\text { Dyeing times } \\
\text { (minutes) }\end{array}$} & 15 & 1.794 & 14.7 \\
\hline & 30 & 1.718 & 9.8 \\
\hline & 45 & 1.660 & 6.1 \\
\hline & 60 & 1.628 & 4.1 \\
\hline
\end{tabular}



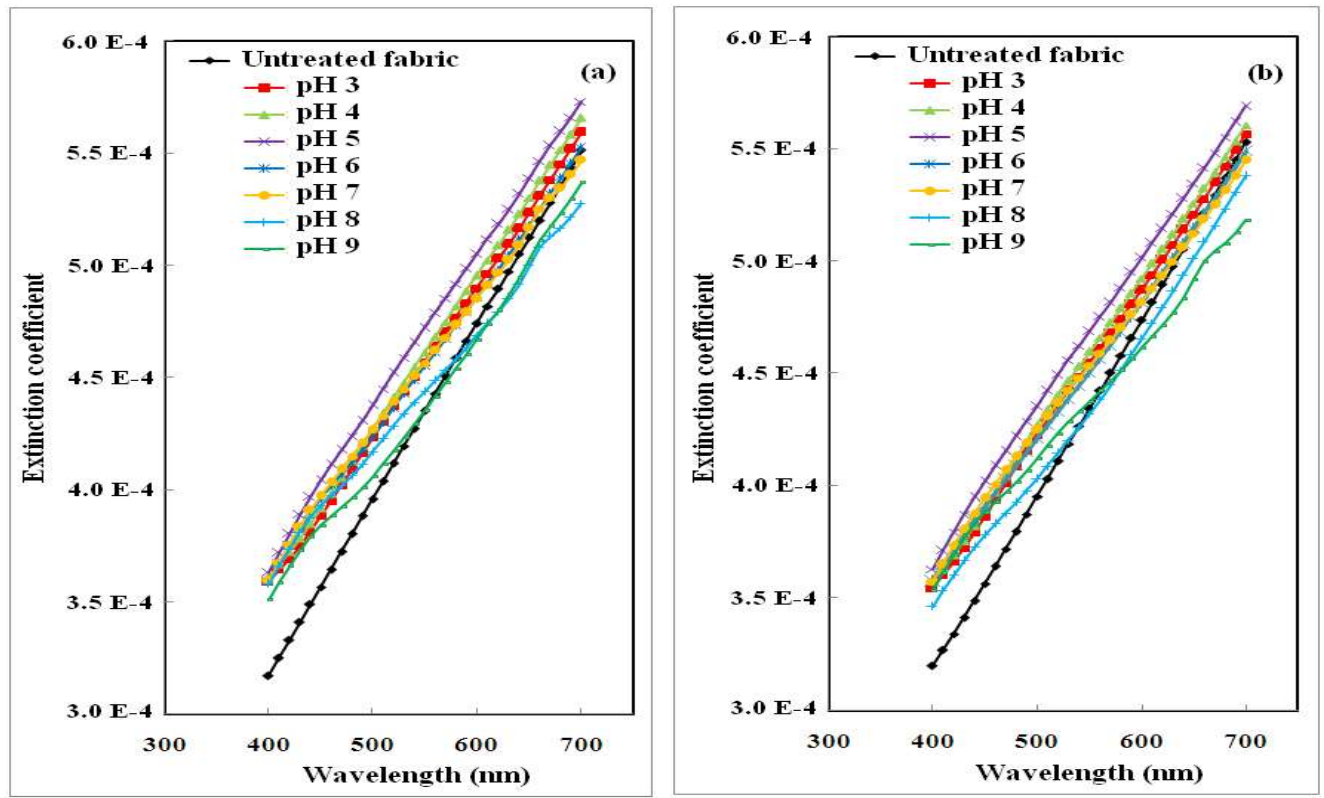

Figure 20. Dependence of the extinction coefficient on wavelength for undyed and neem dyed silk fabrics with different dye bath $\mathrm{pH}$ values before (a) and after (b) exposure.
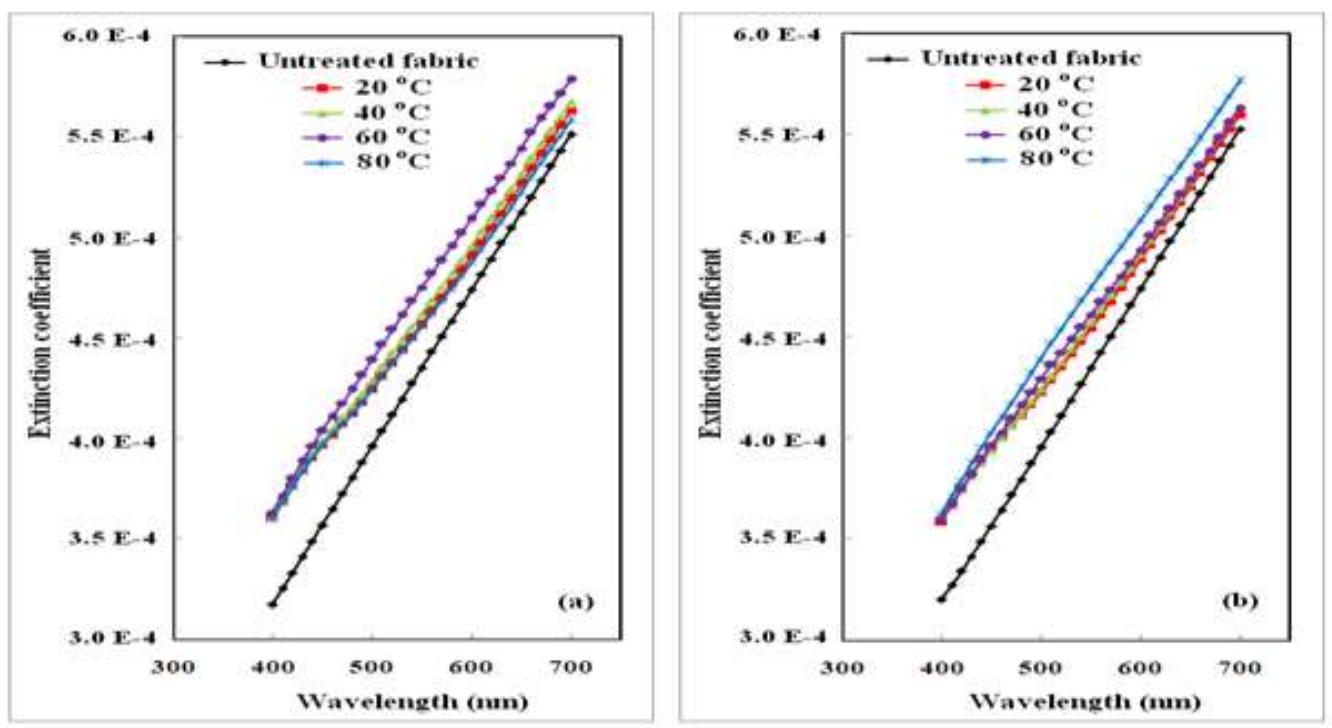

Figure 21. Dependence of the extinction coefficient on wavelength for undyed and neem dyed silk fabrics with different dye bath temperatures before (a) and after (b) exposure. 

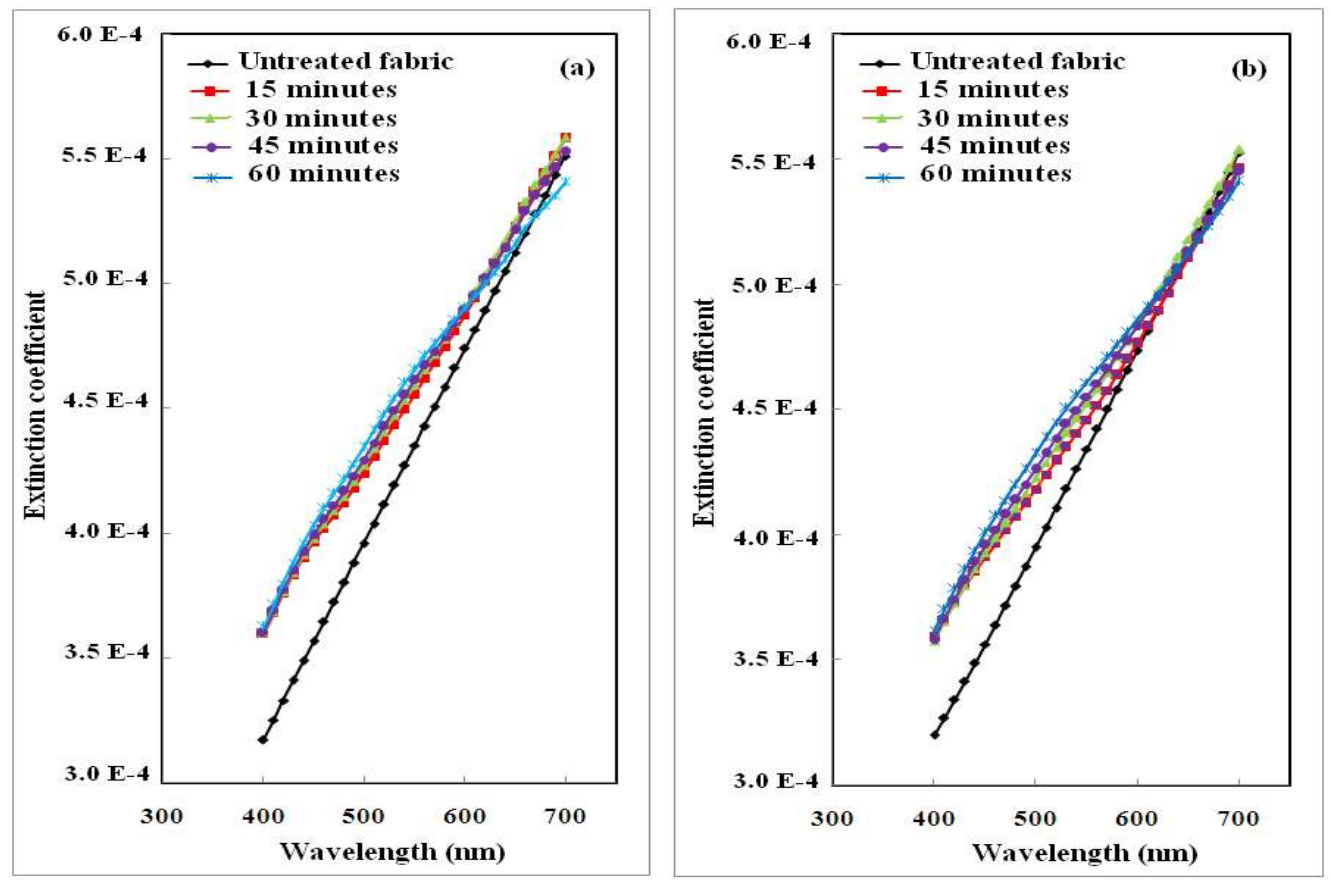

Figure 22. Dependence of the extinction coefficient on wavelength for undyed and neem dyed silk fabrics with different dye bath times before (a) and after (b) exposure.

A close relationship to the amount of dye absorbed by the fabric under different dye bath conditions (dye bath $\mathrm{pH}$ values, temperatures and times) was obtained by determining the color strength $(\alpha / \mathrm{S})$ values from the diffuse reflectance of the fabrics (Eq. 3). Figs. 23-25 show the variations of the color strength as functions of wavelength for undyed and neem dyed silk fabrics with different dye bath conditions ( $\mathrm{pH}$ values, temperatures and times) before (a) and after (b) exposure to artificial day light for $160 \mathrm{~h}$. All the samples show same trends; $\alpha / \mathrm{S}$ values decrease by increasing the wavelength from up to $700 \mathrm{~nm}$. The decrease in color strength by increasing $\mathrm{pH}$ values up to 5 related to the less availability of dyed molecules which indicated that dye bath $\mathrm{pH}$ was one of the most important parameter that must be control (Figure 23). As illustrated in Figure 24a, at different dye bath temperatures before exposure, it was clear that, by increasing the temperature up to $60{ }^{\circ} \mathrm{C}$, the values of $\alpha / \mathrm{S}$ increase and then decrease sharply at $80{ }^{\circ} \mathrm{C}$ which may be due to shrinkage in silk fabrics was caused. This indicates that dyeing silk fabrics with dye bath temperature equals $80^{\circ} \mathrm{C}$ is not preferable. After exposure to artificial day light (Figure 24b), $\alpha / \mathrm{S}$ values for all samples increase by increasing temperature up to $80{ }^{\circ} \mathrm{C}$. As illustrated in Figure 25 for silk fabrics dyeing with different neem dye bath times, similar explanation was introduced as mentioned for the effect of different dye bath temperatures.

The increase in $\alpha / \mathrm{S}$ values by increasing temperature or time was related to number of parameters such as: affinity, heat of sorption as well as accessibility dyeing temperature affected the exhaustion of natural dye onto substrates. The highest $\alpha / \mathrm{S}$ values at higher temperature or time may be explained as neem dye gives a bright color on the dyed fabric besides it can be absorbed on silk through interaction with terminal amino groups $\left(\mathrm{NH}_{2}\right)$ and also through non-ionic interactions with groups along the chain $[51,52]$. However, the number of groups in silk is much enough to give this highest dyeability. Also, the high value of $\alpha / \mathrm{S}$ for the silk samples can be related to the dye structure which allow to form a covalent bond between its groups and non-charged $\left(-\mathrm{NH}_{2}\right)$ amino or ionized hydroxyl $(-\mathrm{OH})$ in silk fabric and the reaction pertain to nucleophilic substitution reaction in the aromatic series [53]. 

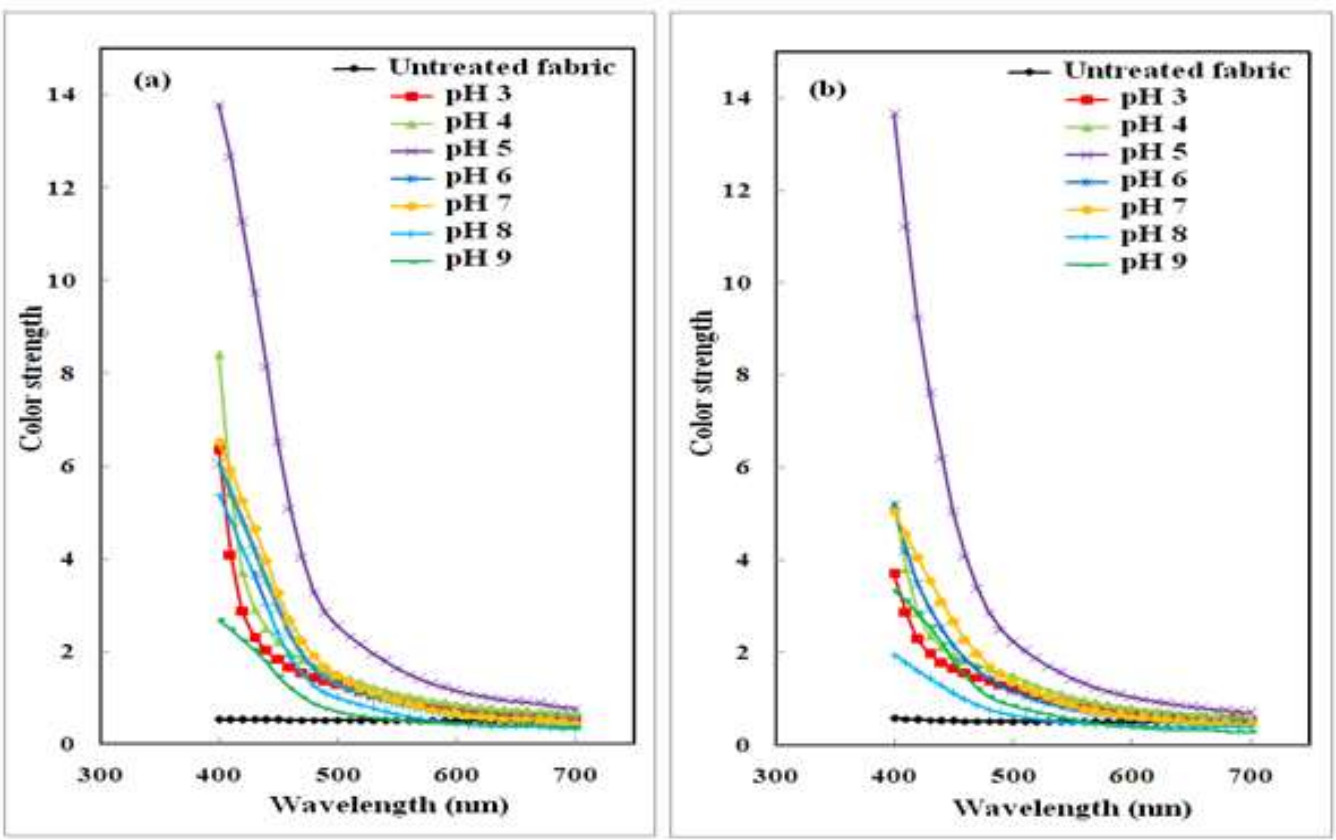

Figure 23. Dependence of the color strength on wavelength for undyed and neem dyed silk fabrics with different dye bath $\mathrm{pH}$ values before (a) and after (b) exposure.
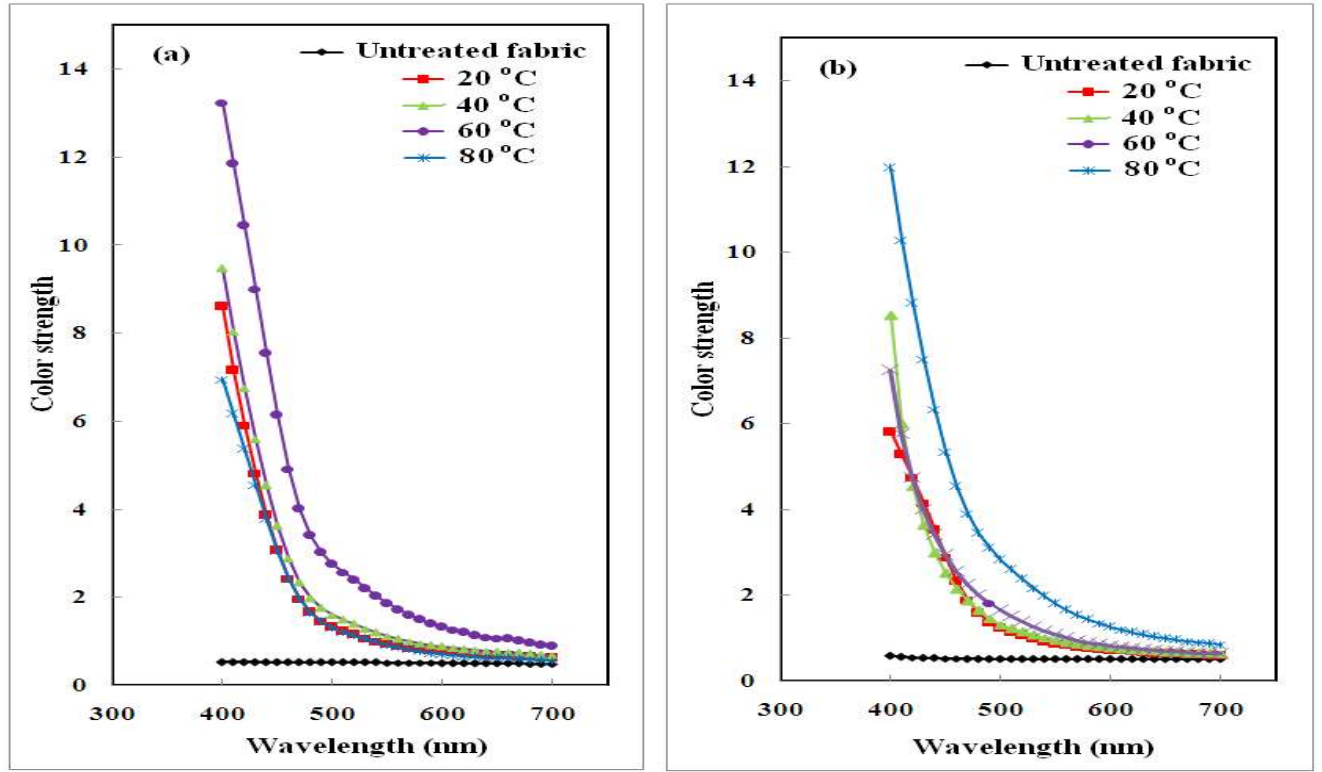

Figure 24. Dependence of the color strength on wavelength for undyed and neem dyed silk fabrics with different dye bath temperatures before (a) and after (b) exposure. 

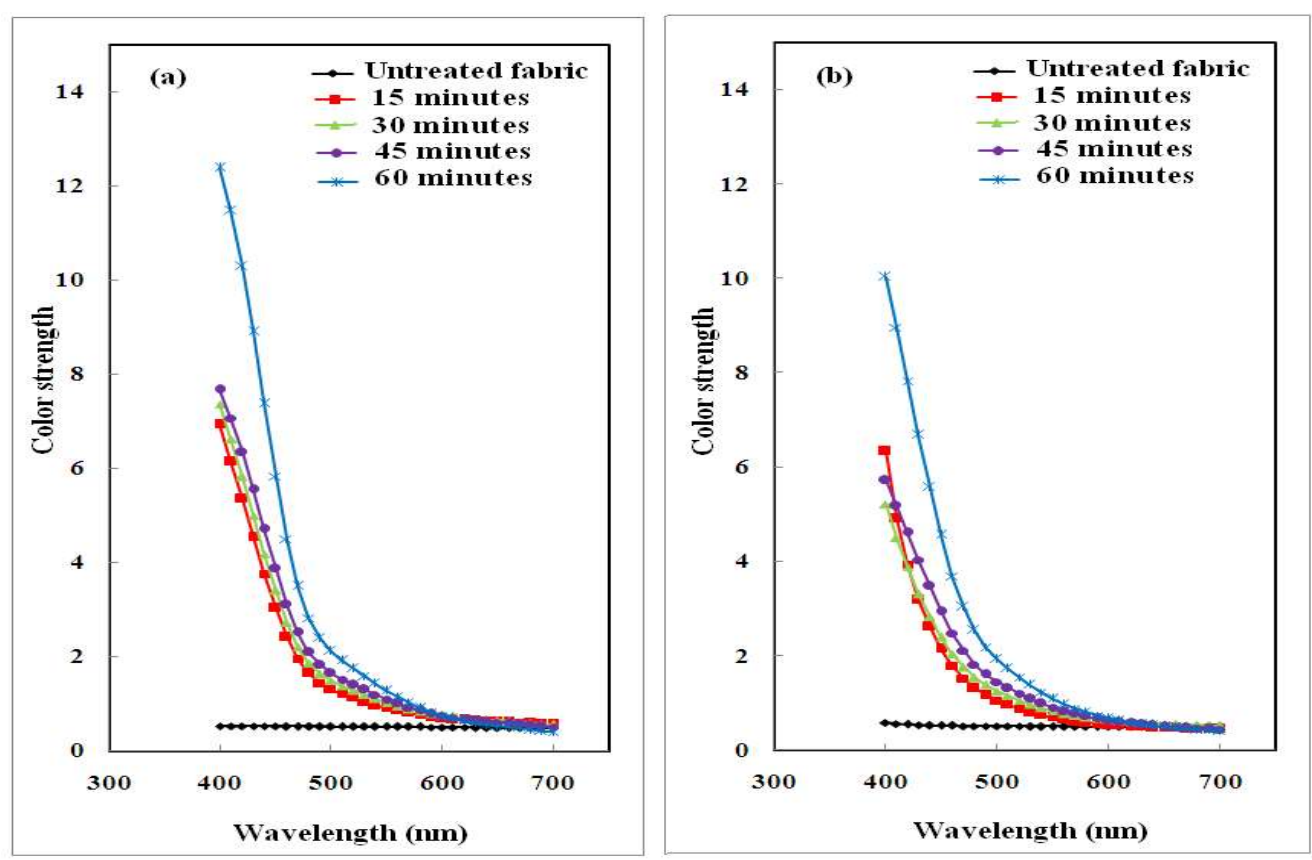

Figure 25. Dependence of the color strength on wavelength for undyed and neem dyed silk fabrics with different dye bath times before (a) and after (b) exposure.

\section{Conclusions}

The present work shows that, Azadirachta indica leaves of neem can be used as dye for coloring textiles. The process of extraction was simple and environmental friendly. The natural colorant extracted from leaves of neem was successfully used as an eco-friendly dye to obtain different shades of yellow. It was found that neem dye can be used for dyeing of silk fabrics under different conditions such as $\mathrm{pH}$ values, temperatures and times to obtain wide range for soft hell shades. The use of this natural dye can be therefore being a potential substitute for the synthetic dyes.

From the obtained results, it was concluded that, with respect to the chemical structure of neem dye, the CIE tristimulus values and color parameters values as well as absorption coefficient, extinction coefficient and color strength, were found to be influenced by either different neem dye bath $\mathrm{pH}$ values, temperatures and times or by exposure to artificial day light for $160 \mathrm{~h}$.

\section{ORCID}

Nabawia A. Abdel-Zaher: 0000-0001-6952-4548

Manal T.H. Moselhey: 0000-0003-3826-1225

Osiris W. Guirguis: 0000-0003-3670-2904

\section{References}

[1] J. Guan, Ch. Q. Yang and G. Chen (2009). Formaldehyde-free flame retardant finishing of silk using a hydroxyl-functional organophosphorus oligomer, Polym. Degrad. Stab. 94, 450-455.

[2] F. Vollrath (1999). Biology of spider silk, Int. J. Biol. Macromol. 24, 81-88.

[3] H. P. Zhao, X. Q. Feng, S. W. Yu, W. Z. Cui and F. Z. Zou (2005). Mechanical properties of silkworm cocoons, Polymer, 46, 9192-9201.

[4] H.-Y. Cheung, K.-T. Lau, M.-P. Ho and A. Mosallam (2009). Study on the mechanical properties of different silkworm silk fibers, J. Compos. Mater. 43, 2521-2531.

[5] G. H. Altman, F. Diaz, C. Jakuba, T. Calabro, R. L. Horan, J. Chen, H. Lu, J. Richmond and D. L. Kaplan (2003). Silkbased biomaterials, Biomaterials, 24, 401-416. 
[6] T. Ari, G. Freddi, R. Innocenti and M. Tsukada (2004). Biodegradation of Bombyx mori silk fibroin fibers and films, $J$. Appl. Polym. Sci. 91, 2383-2390.

[7] I. C. Um, H. Y. Kweon, C. M. Hwang, B. G. Min and Y. H. Park (2002). Structural characteristics and properties of silk fibroin/polyurethane blend films, Int. J. Ind. Entomol. 5, 163-170.

[8] M. Santin, A. Motta, G. Freddi and M. Cannas (1999). In vitro evaluation of the inflammatory potential of the silk fibroin, J. Biomed. Mater. Res. A, 46, 382-389.

[9] P. M. Cunniff, S. A. Fossey, M. A. Auerbach, J. W. Song, D. L. Kaplan, W. Wade Adams, R. K. Eby, D. Mahoney and D. L. Vezie (1994). Mechanical and thermal properties of dragline silk from the spider Nephila clavipes, Polym. Advan. Technol. 5, 401-410.

[10] J. M. Gosline, M. W. Denny and M. Demont (1984). Spider silk as rubber, Nature, 309, 551-2.

[11] J. M. Gosline, M. E. Demont and M. W. Denny (1986). The structure and properties of spider silk, Endeavour, 10, $37-43$.

[12] J. Pérez-Rigueiro, C. Viney, J. Llorca and M. Elices (2000). Mechanical properties of single-brin silkworm silk, J. Appl. Polym. Sci. 75, 1270-1277.

[13] Y. Kawahara and M. Shioya (1997). Mechanical properties of tussah silk fibers treated with methacrylamide, J. Appl. Polym. Sci. 65, 2051-2057.

[14] M. M. R. Khan, H. Morikawa, Y. Gotoh, M. Miura, Z. Ming, Y. Sato and M. Iwasa (2008). Structural characteristics and properties of Bombyx mori silk fiber obtained by different artificial forcibly silking speeds, Int. J. Biol. Macromol. 42, 264270.

[15] M. Z. Li, C. S. Zhang, S. Z. Lu, Z. Y. Wu and H. J. Yan (2002). Study on porous silk fibroin materials: 3. Influence of repeated freeze-thawing on the structure and properties of porous silk fibroin materials, Polym. Advan. Technol. 13, 605610.

[16] J. P. Rigueiro, M. Elices, J. Llorca and C. Viney (2002). Effect of degumming on the tensile properties of silkworm (Bombyx mori) silk fiber, J. Appl. Polym. Sci. 84, 1431-1437.

[17] D.E. Chung, H.H. Kim, M.K. Kim, K.H. Lee, Y. H. Park and I.C. Um (2015). Effects of different Bombyx mori silkworm varieties on the structural characteristics and properties of silk, Int. J. Biol. Macromol. 79, 943-951.

[18] J. Kim, C. H. Kim, C. H. Park, J. N. Seo, H. Kweon, S. W. Kang SW and K. G. Lee (2010). Comparison of methods for the repair of acute tympanic membrane perforations: silk patch vs. paper patch, Wound Repair Regen. 18, 132-138.

[19] H. Y. Kweon, K.G. Lee, C.H. Chae, C. Balázsi, S.-K. Min, J.-. Kim, J. Choi and S. G. Kim (2011). Development of nanohydroxyapatite graft with silk fibroin scaffold as a new bone substitute, J. Oral. Maxil. Surg. 69, 1578-1586.

[20] J.Y. Song, S.G. Kim, J.W. Lee, W.S. Chae, H. Y. Kweon, Y.Y. Jo, K.G. Lee, Y.C. Lee, J.Y. Choi and J.Y. Kim (2011). Accelerated healing with the use of a silk fibroin membrane for the guided bone regeneration technique, Oral Surg. Oral Med. O. 112, e26-e33.

[21] H.J. Jin, J. Chen, V. Karageorgiou, G. H. Altman and D. L. Kaplan (2004). Human bone marrow stromal cell responses on electrospun silk fibroin mats, Biomaterials, 25, 1039-1047.

[22] U. J. Kim, J. Park, H. J. Kim, M. Wada and D. L. Kaplan (2005). Three-dimensional aqueous-derived biomaterial scaffolds from silk fibroin, Biomaterials, 26, 2775-2785.

[23] W.Y. Lee, I. C. Um, M.K. Kim, K.J. Kwon, S.G. Kim and Y. W. Park (2014). Effectiveness of woven silk dressing materials on full-skin thickness burn wounds in rat model, Maxillofac. Plast. Reconstr. Surg. 36, 280-284.

[24] S. Y. Park, C. S. Ki, Y. H. Park, K. G. Lee, S. W. Kang, H. Y. Kweon and H. J. Kim (2015). Functional recovery guided by an electrospun silk fibroin conduit after sciatic nerve injury in rats, J. Tissue Eng. Regen. Med. 9, 66-76.

[25] L. Li, S. Puhl, L. Meinel and O. Germershaus (2014). Silk fibroin layer-by-layer microcapsules for localized gene delivery, Biomaterials, 35, 7929-7939.

[26] S. Ahmad Khan, M. Ibrahim Khan, M. Yusuf, M. Shahid, F. Mohamed and A. Ali Khan (2011). Natural dyes shades on woollen yarn dyed with Kamala (Mallotus philippinesis) using eco friendly metal mordants and their combination, Colourage, 58, 38-44.

[27] A. D. Broadbent (2011). Basic principles of textile coloration, Society of Dyers and Colorists: Canada.

[28] D. N. Tewari (1999). Monograph on neem (Azadirachta indica A. Juss.), Indian Council of Forestry Research and Education (ICFRE), International Book Distributors: Dehra Dun.

[29] U. Francine, U. Jeannette and R. J. Pierre (2015). Assessment of antibacterial activity of neem plant (Azadirachta indica) on Staphylococcus aureus and Escherichia coli, J. Med. Plants Studies, 3, 85-91.

[30] S. Ganguli (2002). Neem: A therapeutic for all seasons, Current Science, 82, 1304-1312.

[31] S. Maragatharavlli, S. Brinda, N. S. Kaviyaarshi and S. R. Gangwar (2012). Antimicrobial activity in leaf extract of neem (Azadirachta indica Linn.), Int. J. Sci. Nature, 3, 110-113.

[32] R. R. Raut, A. R. Sawant and B. B. Jamge (2014). Antimicrobial activity of Azadirachta indica (neem) against pathogenic microorganisms, J. Acad. Ind. Res. 3, 327-329.

[33] M. S. Khehra, H. S. Saini, D. K. Sharma, B. S. Chadh and S. C. Chimni (2006). Biodegradation of azo dye C.I. Acid Red 88 by an anoxic-aerobic sequential bioreactor, Dyes Pigm. 70, 1-7.

[34] CIE 15, Technical Report: Colorimetry (2004). 3rd edition, International Commission on Illumination: USA; CIE Recommendations on Colorimetry (1986). CIE Publ. No: 15.2. Central Bureau of the CIE: Vienna; CIE Recommendations on Uniform Color Spaces, Color Difference Equations, Psychometric Color Terms (1971;1978). Suppl. No. 2 of CIE Publ. No. 15 (E-1.3.1): Paris.

[35] R. M. Christi, R. R. Mather and R. H. Wardman (2000). The chemistry of colour application, 1st edition, Oxford: John Wiley \& Sons Ltd, Blackwell Science Ltd.

[36] G. S. Grover and J. T. Rao (1979). Investigation on the antimicrobial efficiency of essential oils Ocimum sanctum and Ocimum gratissimum, Perfum. Kosmet, 56, 50-52. 
[37] H. Schmutterer (1995). The neem tree Azadirachta indica A. Juss and other meliaceous plants: Sources of unique natural products for integrated pest management, medicine, industry and other purposes, In: Schmutterer H, editor. Germany: Weinheim $\mathrm{VCH}$.

[38] O. W. Guirguis and M. T. H. Moselhey (2011). Optical study of poly(vinyl alcohol)/hydroxypropyl methylcellulose blends, J. Mater. Sci. 46, 5775-5789.

[39] D. B. Judd and G. Wyszecki (1975). Color in business science and industry, 3rd edition, New York: John Wiley \& sons Inc.

[40] A. A. Maradulin, E. W. Montroll, G. H. Weiss (1963). Theory of lattice dynamics in the harmonic approximation, New York: Academic Press.

[41] N. F. Mott and E. A. Davis (1979). Electronic processes in non-crystalline materials, Oxford: Clarendon.

[42] R. Tintu, K. Saurav, K. Sulakshna, V. P. N. Nampoori, P. Radhakrishnan and S. Thomas (2010). Ge $28 \mathrm{Se}_{60} \mathrm{Sb}_{12} / \mathrm{PVA}$ composite films for photonic applications, J. Non-oxide Glass. 2, 167-174.

[43] D. L. Wood and J. Tauc (1972). Weak absorption tails in amorphous semiconductors, Phys. Rev. B, 5, 3144-3150.

[44] L. Peter, C. L. Bird and W. S. Boston (1975). Theory of coloration of textiles, Bradford, England: Dyers Company Publication Trust.

[45] E. S. Al-Amoudy and A. A. El-Ebissy (2015). Optical studies of cotton fabrics dyed with a natural dye, Brit. J. Appl. Sci. Technology, 9, 159-171.

[46] A. Miller (1994). Handbook of optics, Vol. 1, New York: McGraw-Hill.

[47] S. M. Robertson (1973). Dyes from plants, New York, Toronto, London: Van Nostrand Reinhold Company.

[48] F. H Abd El-Kader, S. A. Gafer, A. F. Basha, S. I. Bannan and M. A. F. Basha (2010). Thermal and optical properties of gelatin/poly(vinyl alcohol) blends, J. Appl. Polym. Sci. 118, 413-420.

[49] R. A. Chikwenze and M. N. Nnabuchi (2010). Effect of deposition medium on the optical and solid state properties of chemical bath deposited CdSe thin films, Chalcogenide Lett. 7, 389-396.

[50] J. I. Pankove (1975). Optical process in semiconductors, New York: Devers Publication.

[51] L. A. Holt and B. Milligan (1977). The formation of carbonyl groups during irradiation of wool and its relevance to photoyellowing, Text. Res. J. 47, 620-624.

[52] F. Sadovkorchagin, A. Maketsky (1970). Chemical technology of fibrous material, London: MIR Publishers.

[53] A. Hebeish (1987). Development in textile chemistry and chemical technology, Cairo: Academy of Scientific Research and Technology.

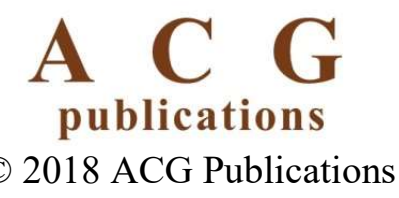

